\title{
Impacts of climate change on groundwater flooding and ecohydrology in lowland karst
}

\author{
Patrick Morrissey $^{1}$, Paul Nolan $^{3}$, Ted McCormack ${ }^{2}$, Paul Johnston ${ }^{1}$, Owen Naughton ${ }^{2}$, Saheba Bhatnagar $^{1}$, and \\ Laurence Gill ${ }^{1}$ \\ ${ }^{1}$ Department of Civil, Structural and Environmental Engineering, Trinity College Dublin, University of Dublin, \\ Museum Building, College Green, Dublin 2, Ireland \\ ${ }^{2}$ Groundwater and Geothermal Unit, Geological Survey of Ireland, Beggar's Bush, Haddington Road, Dublin 4, Ireland \\ ${ }^{3}$ Irish Centre for High-End Computing (ICHEC), 2, Seventh floor, Tower Building, Trinity Technology and Enterprise \\ Campus, Grand Canal Quay, Dublin 2, Ireland
}

Correspondence: Patrick Morrissey (morrispj@tcd.ie)

Received: 1 May 2020 - Discussion started: 8 June 2020

Revised: 31 December 2020 - Accepted: 8 February 2021 - Published: 12 April 2021

\begin{abstract}
Lowland karst aquifers can generate unique wetland ecosystems which are caused by groundwater fluctuations that result in extensive groundwater-surface water interactions (i.e. flooding). However, the complex hydrogeological attributes of these systems, linked to extremely fast aquifer recharge processes and flow through well-connected conduit networks, often present difficulty in predicting how they will respond to changing climatological conditions. This study investigates the predicted impacts of climate change on a lowland karst catchment by using a semi-distributed pipe network model of the karst aquifer populated with output from the high spatial resolution $(4 \mathrm{~km})$ Consortium for Small-scale Modelling Climate Lokalmodell (COSMOCLM) regional climate model simulations for Ireland. An ensemble of projections for the future Irish climate were generated by downscaling from five different global climate models (GCMs), each based on four Representative Concentration Pathways (RCPs; RCP2.6, RCP4.5, RCP6.0 and RCP8.5) to account for the uncertainty in the estimation of future global emissions of greenhouse gases. The onedimensional hydraulic/hydrologic karst model incorporates urban drainage software to simulate open channel and pressurised flow within the conduits, with flooding on the land surface represented by storage nodes with the same stage volume properties of the physical turlough basins. The lowland karst limestone catchment is located on the west coast of Ireland and is characterised by a well-developed conduitdominated karst aquifer which discharges to the sea via in-
\end{abstract}

tertidal and submarine springs. Annual above ground flooding associated with this complex karst system has led to the development of unique wetland ecosystems in the form of ephemeral lakes known as turloughs; however, extreme flooding of these features causes widespread damage and disruption in the catchment. This analysis has shown that mean, 95th and 99th percentile flood levels are expected to increase by significant proportions for all future emission scenarios. The frequency of events currently considered to be extreme is predicted to increase, indicating that more significant groundwater flooding events seem likely to become far more common. The depth and duration of flooding is of extreme importance, both from an ecological perspective in terms of wetland species distribution and for extreme flooding in terms of the disruption to homes, transport links and agricultural land inundated by flood waters. The seasonality of annual flooding is also predicted to shift later in the flooding season, which could have consequences in terms of ecology and land use in the catchment. The investigation of increasing mean sea levels, however, showed that anticipated rises would have very little impact on groundwater flooding due to the marginal impact on ebb tide outflow volumes. Overall, this study highlights the relative vulnerability of lowland karst systems to future changing climate conditions, mainly due to the extremely fast recharge which can occur in such systems. The study presents a novel and highly effective methodology for studying the impact of climate change in lowland karst systems by coupling karst hy- 
drogeological models with the output from high-resolution climate simulations.

\section{Introduction}

Climate projections indicate that a shift in the magnitude and pattern of precipitation is likely to alter catchment runoff regimes in Ireland (Nolan et al., 2017; Blöschl et al., 2019; Murphy et al., 2019). As a consequence, extreme events, such as floods and droughts, are expected to increase in frequency and intensity (Noone et al., 2017; Blöschl et al., 2019). These predicted changes in precipitation will undoubtedly impact groundwater resources and groundwater-related phenomena, such as groundwater flooding and groundwater-dependent wetland habitats. Many studies have previously attempted to postulate the likely impacts of climate change on groundwater resources without using a combination of numerical models driven by climate data derived from global climate models (GCMs; Dragoni and Sukhija, 2008; Howard and Griffith, 2009; Taylor et al., 2013; Meixner et al., 2016). These studies also tend to focus on groundwater resources in terms of the provision of a potable water supply or irrigation and so have not been considering groundwater flooding or ecohydrology in detail. They have also not been focused on groundwater systems dominated by karst flow. Studies into the impacts of climate change have been carried out for the chalk aquifers of southwestern England, which have high porosity and are prone to karstification. Jackson et al. (2015) utilised a distributed ZOOMQ3D groundwater model of the chalk aquifer, with various emission scenario input data, to investigate the predicted changes in groundwater levels. Brenner et al. (2018) conducted a further study of this chalk catchment and showed that projected climate changes may lead to generally lower groundwater levels and a reduction in exceedances of high groundwater level percentiles in the future. Chen et al. (2018) conducted a study into the effects of climate change on alpine karst using GCM data. However, the results of these studies are not directly relevant to lowland karst, with significant groundwater-surface water interactions and associated ecohydrological habitats (groundwaterfed wetlands). In order to assess the future risks relating to groundwater flooding and ecohydrology in lowland karst, it is imperative to understand the complex hydrological processes governing groundwater flow in karst bedrock and how it will likely be altered in the future (Morrissey et al., 2020). In this context, various forms of numerical models are usually applied to describe the hydrological processes in karst catchments (Fleury et al., 2009; Gill et al., 2013a; Hartmann et al., 2013; Hartmann, 2017, Mayaud et al., 2019), which can accurately simulate the groundwater flow and flooding processes which typically occur. Global and distributed models have been successfully applied to simulate lowland karst, with lumped models typically favoured due to their ease of use in gauged catchments. When considering ecohydrology (specifically groundwater-dependent terrestrial ecosystems GWDTE), droughts and extreme floods present the greatest climatological threat, and therefore, the impacts of predicted climate change are of immediate concern. Whilst fluvial models (models which simulate flow with rivers) are relatively straightforward to calibrate and couple with the output from global or regional climate models, groundwater (and specifically karst) models can be more difficult to apply in such a manner, particularly in terms of assessing the resultant output (Hartmann, 2017). Predicting extreme values with limited gauging data follows established, wellvalidated methodologies (Griffis and Stedinger, 2007; Shaw et al., 2011; Ahilan et al., 2012); however, no such established methods appear to be available currently for groundwater flooding in karst systems.

The phenomenon of groundwater flooding in general has become more reported as a natural hazard in recent decades following extensive damage to property and infrastructure across Europe in the winter of 2000-2001 (Finch et al., 2004; Pinault et al., 2005; Hughes et al., 2011). Significant groundwater flooding also occurred in the UK at Oxford (2007) and at Berkshire Downs and Chilterns (2014) and in Galway, Ireland, in 2009 and 2015-2016 (Naughton et al., 2017). Groundwater flooding occurs when the water table rises above the land surface flooding areas often for prolonged periods (often many weeks or months). This compares to fluvial flooding, which occurs when river (or lake) systems overflow their banks and flow into the surrounding lands. Fluvial flooding typically occurs in a sudden (or dramatic) and sometimes dangerous manner following intense rainfall and dissipates relatively quickly (days). Whilst it has been reported that groundwater flooding rarely poses a risk to human life, this form of flooding is known to cause damage and disruption over a long duration, particularly when compared to fluvial flooding (Morris et al., 2008; Cobby et al., 2009). Climate change is also likely to further exacerbate extreme droughts (Murphy et al., 2019), and their frequency and persistence must be quantified if resource planning and protection are to be implemented. Equally, as discussed, the effects of changes in hydrological regimes to wetland ecosystems can be significant; for example, recent studies (Spraggs et al., 2015; Noone et al., 2017) have attempted to quantify the frequency and extent of historic droughts to better understand their recurrence interval and, thus, assess the resilience of different impacted wetland ecosystems. Hence, this study aims to assess the predicted impacts of climate change, particularly during these extreme events, using an ensemble of regional climate models to provide input data into a semidistributed model of a lowland karst catchment in the west of Ireland.

The impact of increasing greenhouse gases and changing land use on climate change can be simulated using global climate models (GCMs). However, long climate simulations using GCMs are currently feasible only with horizontal resolu- 
tions of $\sim 50 \mathrm{~km}$ or coarser. Since climate fields such as precipitation, wind speed and temperature are closely correlated to the local topography, this is inadequate to simulate the detail and pattern of climate change and its effects on the future climate of Ireland. Hence, regional climate models (RCMs) have been developed by dynamically downscaling the coarse information provided by the global models to provide highresolution information on a subdomain covering Ireland. The computational cost of running the RCM, for a given resolution, is considerably less than that of a global model. The approach has its flaws; all models have errors, which are cascaded in this technique, and new errors are introduced via the flow of data through the boundaries of the regional model. Nevertheless, numerous studies have demonstrated that high-resolution RCMs improve the simulation of fields such as precipitation (Kendon et al., 2012; Lucas-Picher et al., 2012; Kendon et al., 2014; Bieniek et al., 2016) and topography-influenced phenomena and extremes with relatively small spatial or short temporal character (Feser et al., 2011; Feser and Barcikowska, 2012; Shkol'nik et al., 2012,; IPCC, 2013). The physically based RCMs explicitly resolve more small-scale atmospheric features and provide a better representation of convective precipitation (Rauscher et al., 2010) and extreme precipitation (Kanada et al., 2008). Other examples of the added value of RCMs include improved simulation of near-surface temperature (Feser, 2006; Di Luca et al., 2016), European storm damage (Donat et al., 2010), strong mesoscale cyclones (Cavicchia and von Storch, 2012), North Atlantic tropical cyclone tracks (Daloz et al., 2015) and near-surface wind speeds (Kanamaru and Kanamitsu, 2007), particularly in coastal areas with complex topography (Feser et al., 2011; Winterfeldt et al., 2011). The Intergovernmental Panel on Climate Change (IPCC) have concluded that there is "high confidence that downscaling adds value to the simulation of spatial climate detail in regions with highly variable topography (e.g. distinct orography, coastlines) and for mesoscale phenomena and extremes" (IPCC, 2013).

\section{Study catchment}

Groundwater flooding in Ireland predominantly occurs within the lowland limestone areas in the west of the country (Naughton et al., 2012, 2018). This flooding is governed by complex interactions between ground and surface waters, with sinking and rising rivers or streams common and surface water features absent completely in many areas (Drew, 2008). The flooding is controlled by complex geology whereby the dominant drainage path for many catchments is through the karstified limestone bedrock. During intense or prolonged rainfall, the limestone bedrock is unable to drain recharge due to the limited storage available within the bedrock (fractures and conduits). Turloughs occur in glacially formed depressions in karst, which intermittently flood on an annual cycle via groundwater sources, and have substrate and/or ecological communities characteristic of wetlands. Geomorphologically, they are a variant on a polje, which are generally larger and more flat-bottomed enclosed depressions in karst landscapes (Ford and Williams, 2007). In Ireland, the most susceptible region to groundwater flooding is the South Galway lowlands, centred around the town of Gort, which is a lowland karst catchment covering an area of approximately $500 \mathrm{~km}^{2}$ (Naughton et al., 2018).

The lowland karst catchment is made up of two distinct bedrock geologies, with the upland mountainous areas to the east underlain by Old Red Sandstone, and the lowlands in the west underlain by highly permeable karstified Carboniferous Limestone. The presence of a permeable epikarst with a welldeveloped conduit and cave system dispersed throughout the limestone portion of the catchment has given rise to a very distinct surface hydrology in which large volumes of water are exchanged between the surface and subsurface across the lowlands through sinking streams, large springs and estavelles (Naughton et al., 2018). A total of three rivers flow off the Slieve Aughty mountains (much of which are covered in blanket bog and forestry), providing allogenic recharge into the lowland karst, and a fourth flows into the catchment from the southwest. Once these watercourses contact the limestone, they disappear into the bedrock where flow occurs within caves or conduits (see Fig. 1). The rivers reappear for short intervals at a number of locations before discharging to the sea via submarine groundwater discharge (including springs located at the intertidal zone of the bay) at Kinvara Bay (Gill et al., 2013b). The groundwater conduit network surcharges to the ground surface through estavelles and springs following periods of sustained heavy rainfall when sufficient capacity is not available in the bedrock to store and convey water to the sea. The excess surface water floods turloughs and interconnected floodplains across the catchment. Extensive and damaging flooding associated with these turloughs has occurred twice in the last decade, leading to considerable cost and disruption. An extreme flood event which occurred in November 2009 was the most severe on record, until it was surpassed in many areas by the events of 20152016. These floods led to over $24 \mathrm{~km}^{2}$ of land being inundated for up to 6 months. The apparent increase in the frequency with which these hugely damaging extreme flooding events are occurring has made quantifying the likely impact of future climate change a topic of high priority and importance. In addition, given that the entire catchment drains to a series of springs at the coast (some of which are intertidal) the impacts of rising sea level, either in combination or isolation to changing rainfall patterns associated with climate change, are also of concern. 


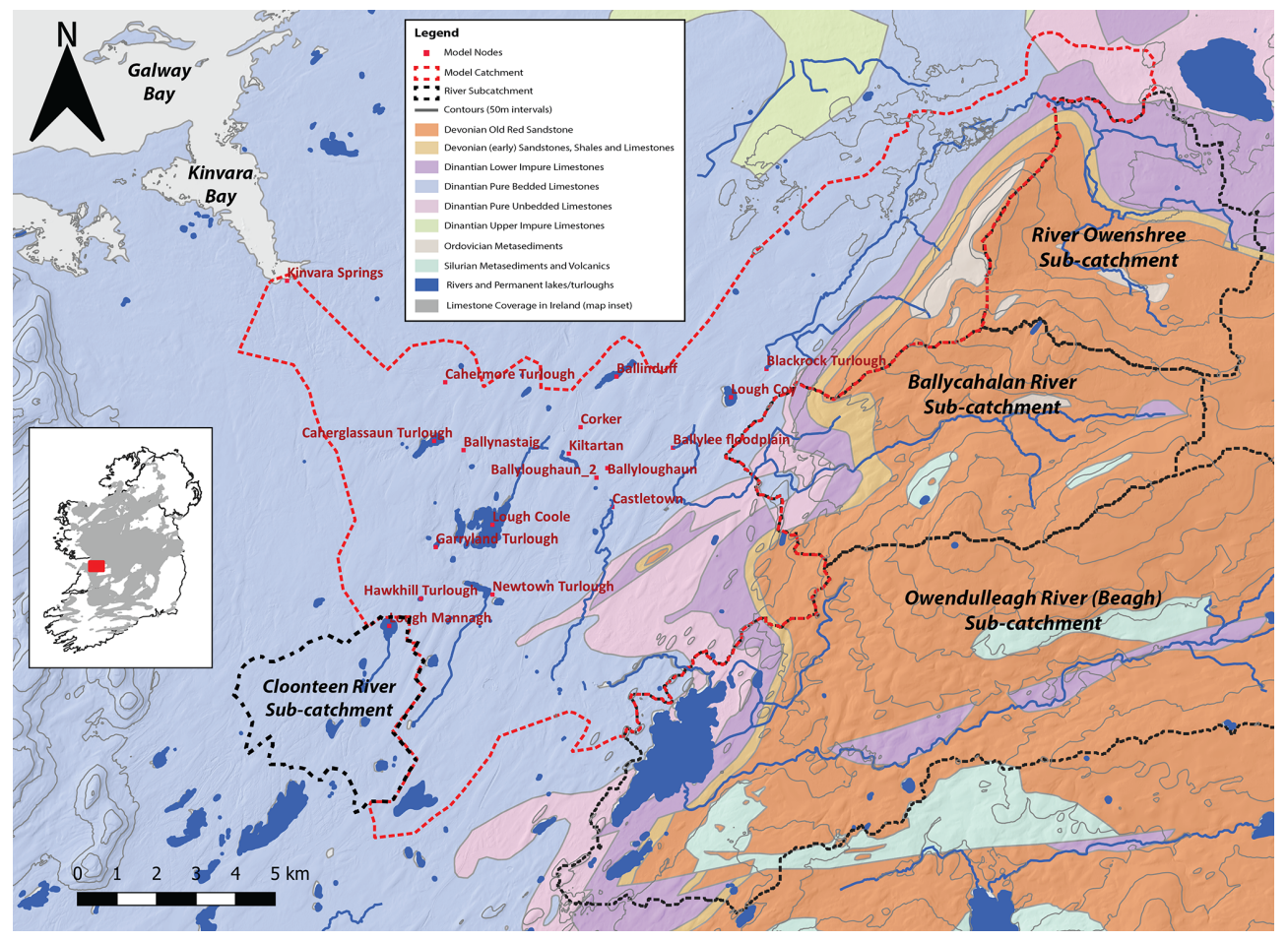

Figure 1. Map of the catchment showing the geology, major rivers and lakes and nodes within the model catchment. This figure contains Irish Public Sector Data (Geological Survey Ireland), licensed under a Creative Commons Attribution 4.0 International (CC-BY 4.0) licence.

\section{Methodology}

\subsection{Climate models and methods}

The future climate of Ireland was simulated at high spatial resolution $(4 \mathrm{~km})$, using the COnsortium for Smallscale Modelling Climate Lokalmodell (COSMO-CLM; v5.0) RCM. The COSMO-CLM regional climate model is the COSMO weather forecasting model in climate mode (https: //www.clm-community.eu, last access: 8 May 2020; Rockel et al., 2008). The COSMO model (http://www.cosmo-model. org, last access: 8 May 2020) is the non-hydrostatic operational weather prediction model used by the German Weather Service (DWD). Projections for the future Irish climate were generated by downscaling the following CMIP5 global data sets: the UK Met Office's Hadley Centre Global Environment Model version 2 Earth System configuration (HadGEM2-ES) GCM, the EC-Earth consortium GCM, the CNRM-CM5 GCM developed by CNRM-GAME (Centre National de Recherches Météorologiques - Groupe d'étude de l'Atmosphere Météorologique) and Cerfacs (Centre Européen de Recherche et de Formation Avancée), the Model for Interdisciplinary Research on Climate (MIROC5) GCM developed by the MIROC5 Japanese research consortium and the MPI-ESM-LR (Earth system model developed by the Max Planck Institute for Meteorology). The Representative Concentration Pathways (RCPs) are greenhouse gas concentration trajectories adopted by the IPCC. The RCPs are focused on radiative forcing - the change in the balance between incoming and outgoing radiation via the atmosphere caused primarily by changes in atmospheric composition - rather than being linked to any specific combination of socioeconomic and technological development scenarios. There are four such scenarios (RCP2.6, RCP4.5, RCP6.0 and RCP8.5) named with reference to a range of radiative forcing values for the year 2100 or after, i.e. 2.6, 4.5, 6.0 and $8.5 \mathrm{~W} / \mathrm{m}^{2}$, respectively (Moss et al., 2010; van Vuuren et al., 2011).

The RCMs were driven by GCM boundary conditions with the following nesting strategy: GCM to $18 \mathrm{~km}$ and GCM to $4 \mathrm{~km}$. For the current study, only $4 \mathrm{~km}$ grid spacing RCM data are considered. The higher resolution data allow sharper estimates of the regional variations of climate projections. The climate fields of the RCM simulations were archived at $3 \mathrm{~h}$ intervals.

The mid-century precipitation climate of Ireland is expected to become more variable, with substantial projected increases in both dry periods and heavy precipitation events (Nolan, 2017, 2020). These studies show that substantial decreases in precipitation are projected for the summer months, with reductions ranging from $0 \%$ to $11 \%$ for the RCP 4.5 scenario and from $2 \%$ to $17 \%$ for the RCP8.5 scenario. Other seasons, and over the full year, show relatively small projected changes in precipitation. The frequencies of heavy precipitation events show notable increases over the year as a 
whole and in the winter and autumn months, with projected increases of $5 \%-19 \%$. The number of extended dry periods is also projected to increase substantially by the middle of the century over the full year and for all seasons except spring. The projected increases in dry periods are largest for summer, with values of $+11 \%$ and $+48 \%$ for the RCP 4.5 and RCP8.5 scenarios, respectively. Refer to Fig. 2 for further details.

An overview of the simulations is presented in Table 1. Data from two time slices, 1976-2005 (the control or past) and 2071-2010, were used for analysis of projected changes in the Irish climate by the end of the 21st century. It must be noted that the full RCM simulations in fact covered the entire period 1976-2100, and these time slices were simply used to make a past versus future comparison (Fig. 2 shows results from the full simulation and not just the chosen time slices for this current study). The historical period was compared with the corresponding future period for all simulations within the same RCM-GCM group. This results in future anomalies for each model run; that is, the difference between future and past.

The RCM projection results are in line with previous work (McGrath et al., 2005; McGrath and Lynch, 2008; Gleeson et al., 2013; Nolan et al., 2014, 2017, 2020; Nolan, 2015, O'Sullivan et al., 2015), with enhanced temperature rises predicted by the end of the century of between 0.8 and $3{ }^{\circ} \mathrm{C}$ for the high emission scenario (RCP8.5).

The method of bilinear interpolation was employed to extract $5 \mathrm{~km}$ RCM precipitation and evapotranspiration data at each of the locations of existing rain gauges in the study catchment. The Penman-Monteith FAO-56 method (REF) was used to compute daily evapotranspiration (in millimetres; see Werner et al., 2019 for a full description of methods and validations).

The RCMs were validated by downscaling European Centre for Medium-Range Weather Forecasts (ECMWF) ERAInterim reanalyses and the GCM data sets for multi-decadal time periods and comparing the output with observational data. Extensive validations were carried out to test the ability of the RCMs to accurately model the climate of Ireland. Figure $3 \mathrm{a}$ presents the annual observed precipitation averaged over the period 1981-2000. Figure 3b presents the downscaled ERA-Interim data as simulated by the COSMO5CLM model with $4 \mathrm{~km}$ grid spacings. It is noted that the RCM accurately captures the magnitude and spatial characteristics of the historical precipitation climate, e.g. higher rainfall amounts in the west and over mountains.

Figure $3 \mathrm{c}$ shows that the percentage errors range from approximately $-30 \%$ to approximately $+15 \%$ for COSMO5CLM downscaled ERA-Interim data. The percentage error at each grid point $(i, j)$ is given by the following:

${\operatorname{per} \_\operatorname{bias}_{(i, j)}}=100 \times\left(\frac{\operatorname{bias}_{(i, j)}}{\overline{\operatorname{OBS}}_{(i, j)}}\right)$, where

$\operatorname{bias}_{(i, j)}=\overline{\mathrm{RCM}}_{(i, j)}-\overline{\mathrm{OBS}}_{(i, j)}$,

and the $\overline{\mathrm{RCM}}_{(i, j)}$ and $\overline{\mathrm{OBS}}_{(i, j)}$ terms represent the RCM and observed values, respectively, at grid point $(i, j)$, averaged over the period 1981-2000. Figure 3c highlights a clear underestimation of precipitation over the mountainous regions. This is probably because the RCMs underestimate heavy precipitation; previous validations studies (e.g. Nolan et al., 2017) have demonstrated a decrease in RCM skill with increasing magnitude of heavy precipitation events.

To assess the added value of high-resolution RCM data, and to quantify the improved skill of RCMs over the GCMs, precipitation data were compared with both RCM and GCM data for the period 1976-2005. Results, presented in Table 2, demonstrate the improved skill of the RCMs over the GCMs. Moreover, an increase in grid resolution of the RCMs (from 18 to $4 \mathrm{~km}$ grid spacings) results in a general increase in skill.

For an in-depth validation of the RCMs, please refer to Nolan (2015) and Nolan et al. (2017, 2020), Flanagan et al. (2019, 2020) and Werner et al. (2019), whose results confirm that the output of the RCMs exhibit reasonable and realistic features, as documented in the historical data record, and consistently demonstrate improved skill over the GCMs. The results of these validation analyses confirm that the RCM configurations and domain size of the current study are capable of accurately simulating the climate of Ireland.

\subsection{Karst groundwater model}

A semi-distributed pipe network model of the Gort Lowlands has been developed by the authors using urban drainage software (Infoworks ICM by Innovyze). This model simulates both open channel and pressurised flow within the conduits, with flooding on the land surface represented by storage nodes with the same stage volume properties of the physical turlough basins (Morrissey et al., 2020). The model receives input from the four rivers as a time-varying discharge, which is computed separately using observed river gauging data provided by the Irish Office of Public Works (OPW), utilising established stage discharge rating curves (Gill et al., 2013a). Autogenic recharge across the catchment is represented within the model, using sub-catchments receiving a time series of precipitation and evapotranspiration with inflows to the pipe network controlled by a calibrated groundwater infiltration module (GIM) within the software. The downstream boundary condition for the model is the tidal level in Kinvara Bay, which is taken from the Irish Marine Institute observed data recorded at a buoy in Galway Bay. The model was calibrated and validated over a 30-year period by matching the simulated fluctuation of the groundwatersurface water interactions (i.e. turloughs levels) with observed values and was found to represent the catchment with a very high degree of accuracy (Nash-Sutcliffe efficiency, NSE, and Kling-Gupta efficiency, KGE; > 0.97). The full 
Table 1. Details of the ensemble RCM simulations used in this study. Rows present information on the RCM used, the corresponding downscaled GCM, the RCP used for future simulations, the number of ensemble comparisons and the time slice analysed. In each case, the future 30-year period, 2071-2100, is compared with the past RCM period 1976-2005. The mean of three RCP2.6, five RCP4.5 and five RCP8.5 RCM projections were calculated. The RCP6.0 simulation comprises just one simulation, so it was compared directly with the past RCM period.

\begin{tabular}{|c|c|c|c|c|}
\hline $\mathrm{RCM}$ & GCM & Scenarios & $\begin{array}{l}\text { No. of ensemble } \\
\text { comparisons }\end{array}$ & $\begin{array}{l}\text { Time periods } \\
\text { analysed }\end{array}$ \\
\hline \multirow[t]{10}{*}{ COSMO5 } & \multirow{2}{*}{$\begin{array}{l}\text { EC-Earth } \\
\text { (r1i1p1) }\end{array}$} & Historical & - & 1976-2005 \\
\hline & & RCP4.5, RCP8.5 & 2 & $2071-2100$ \\
\hline & \multirow{2}{*}{$\begin{array}{l}\text { MPI-ESM-LR } \\
\text { (r1i1p1) }\end{array}$} & Historical & - & $1976-2005$ \\
\hline & & RCP2.6, RCP4.5, RCP8.5 & 3 & $2071-2100$ \\
\hline & \multirow{2}{*}{$\begin{array}{l}\text { CNRM-CM5 } \\
\text { (r1i1p1) }\end{array}$} & Historical & - & $1976-2005$ \\
\hline & & $\mathrm{RCP} 4.5, \mathrm{RCP} 8.5$ & 2 & $2071-2100$ \\
\hline & \multirow{2}{*}{$\begin{array}{l}\text { HadGEM2-ES } \\
\text { (r1i1p1) }\end{array}$} & Historical & - & $1976-2005$ \\
\hline & & RCP2.6, RCP4.5, RCP8.5 & 3 & $2071-2100$ \\
\hline & \multirow{2}{*}{$\begin{array}{l}\text { MIROC5 } \\
\text { (r1i1p1) }\end{array}$} & Historical & - & $1976-2005$ \\
\hline & & RCP2.6, RCP4.5, RCP6.0, RCP8.5 & 4 & $2071-2100$ \\
\hline
\end{tabular}

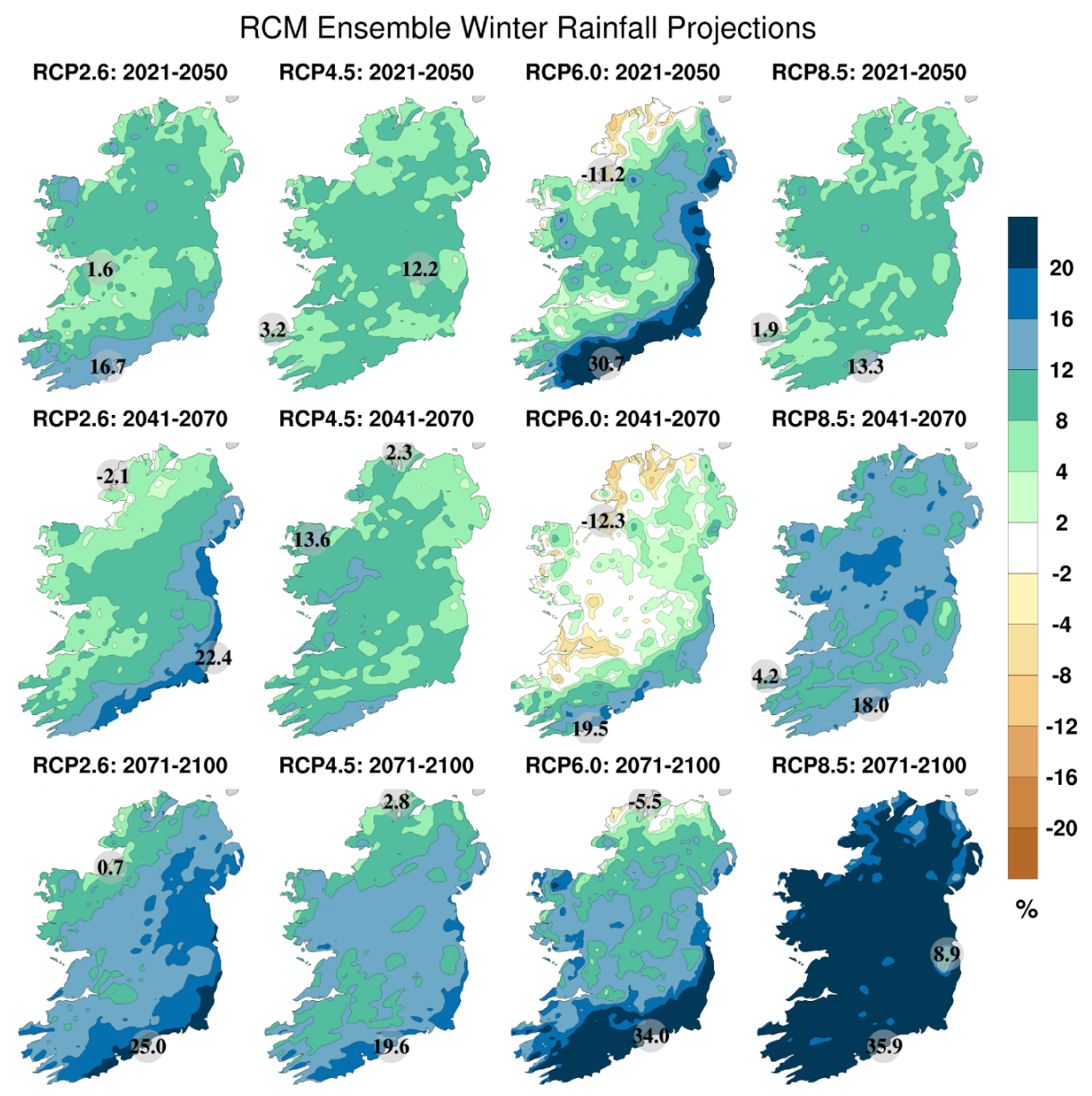

Figure 2. RCM ensemble projections of mean winter rainfall (in percent). The individual ensemble percentage projections are calculated as $100 \times$ (future-past)/past. In each case, the future 30-year periods are compared with the past RCM period 1976-2005. The figure presents the mean of three RCP2.6 (low), five RCP4.5 (medium), one RCP6.0 (medium/high) and five RCP8.5 RCM (high) projections. The numbers included in each plot are the minimum and maximum projected changes, displayed at their locations. (Refer to Fig. 1 for the location of the study catchment). 
(a)

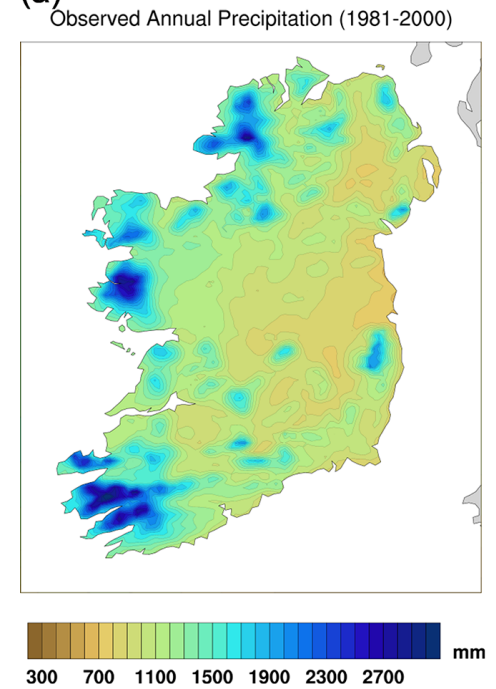

(b)

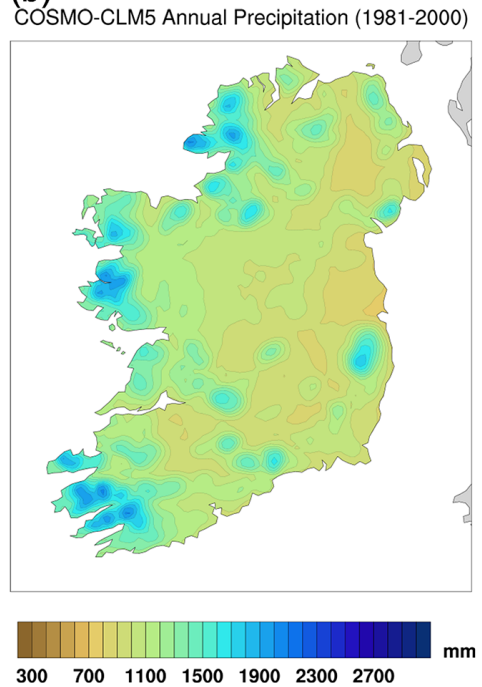

(c)

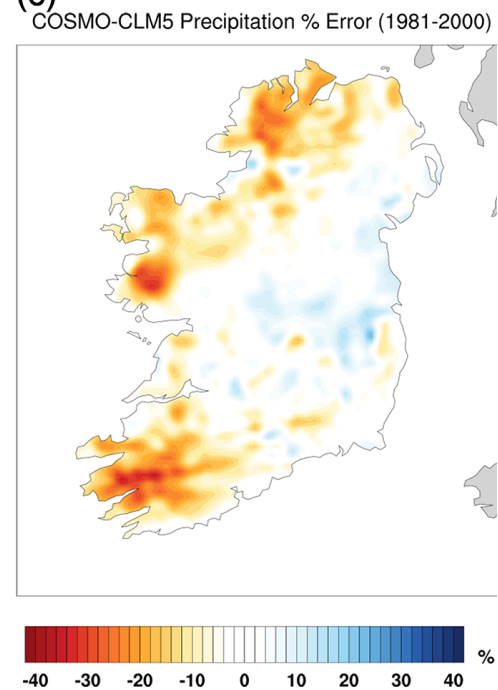

Figure 3. Mean annual precipitation for 1981-2000. (a) Observations, (b) COSMO5-CLM-ERA-Interim 4 km data and (c) COSMO5-CLMERA-Interim error (in percent).

Table 2. GCM and COSMO5-CLM mean absolute error (MAE; in percent) uncertainty estimates through comparison with gridded observations for the period 1976-2005. For each metric, the best- ${ }^{\mathrm{a}}$ and worst-performing ${ }^{\mathrm{b}}$ scores are identified.

\begin{tabular}{lccc}
\hline \multicolumn{4}{c}{ The 30-year average annual rainfall MAE \% error } \\
\hline GCM & GCM data & COSMO5-CLM-GCM & COSMO5-CLM-GCM \\
& & $18 \mathrm{~km}$ & $4 \mathrm{~km}$ \\
\hline CNRM-CM5 & $16.5^{\mathrm{b}}$ & 14.1 & $11.8^{\mathrm{a}}$ \\
EC-Earth (r12i1p1) & $17.3^{\mathrm{b}}$ & 14.0 & $10.0^{\mathrm{a}}$ \\
HadGEM2-ES & $20.8^{\mathrm{b}}$ & $14.6^{\mathrm{b}}$ & 15.1 \\
MIROC5 & $26.0^{\mathrm{b}}$ & 18.2 & $15.6^{\mathrm{a}}$ \\
MPI-ESM-LR & $25.1^{\mathrm{b}}$ & 24.8 & $21.6^{\mathrm{a}}$ \\
\hline
\end{tabular}

model setup and calibration and validation process is presented in Morrissey et al. (2020).

The RCM rainfall and evapotranspiration data, described above, were then used to run the groundwater flow model for each of the historical and future periods, covering 24 simulation periods in total (five past and 19 future). Daily rainfall and evapotranspiration totals were output from the RCM models in all cases, and these values were used as input to rainfall-runoff (RR) and karst models described below. When hourly totals were required to run the model, the daily total was simply evenly distributed over the $24 \mathrm{~h}$ period (this had no impact on the model accuracy; see Morrissey et al. (2020) for further details). The OPW have specified the required allowances in flood parameters which should be made for planning purposes in Ireland (OPW, 2019) for the mid-range and high-end future scenarios (MRFS and HEFS). These provisions make allowances for both mean sea level rises and predicted land movement of $+0.55 \mathrm{~m}$ for the MRFS and $+1.05 \mathrm{~m}$ for the HEFS. Therefore, to quantify the combination effect of rising sea level with changing climatological conditions, the future scenarios were also simulated with the tidal boundary condition adjusted to allow for predicted increases in mean sea level at Kinvara Bay.

The karst model with uncertainty bounds, as outlined in Morrissey et al. (2020), was used to both simulate the past RCM period (1976-2005) and the future time slice (20712100). By comparing the output from the RCM past and future simulations, using the same calibrated model the error or bias within the model itself, is accounted for, and the anomalies between both periods represents the potential changes due to climate change. Other approaches to climate change modelling with GCMs use bias-correction techniques to correct the simulated outputs for the past in order to correct the future and then utilise the differences between the two corrected data sets. This process can introduce further error, given that bias correction for such models is an evolving field. The approach taken in this study has the advantage of eliminating the need for bias correction (which is a recognised method in the literature) and accounts for the karst model uncertainty. 


\section{Results and discussion}

As outlined above, data from two time horizons, 1976-2005 (the control) and 2071-2100, were used to analyse projected changes, by the end of the 21 st century, in the Irish climate. The historical period was compared with the corresponding future period for all simulations within the same group. This results in future changes for each model run, i.e. the difference between the model future and past. While this strategy aims to remove the model bias, as outlined in Nolan et al. (2017), a level of uncertainty is common to all climate models which inherently include bias, particularly with respect to rainfall. Model uncertainty was compared to other karst models to contextualise the results; the reported uncertainty of our model (3\%-14\%) is comparable and within the same window when compared to other reported studies (e.g. Mudarra et al., 2019; Nerantzaki and Nikolaidis, 2020).

\subsection{Statistical analysis}

Considering that flood levels within turloughs are generally not normally distributed (Morrissey et al., 2020), the nonparametric Kolmogorov-Smirnov statistical test was employed to test for statistical significance of projected changes. The Kolmogorov-Smirnov null hypothesis states that the past and future data are from the same continuous distribution. Small values of the confidence level $p$ cast doubt on the validity of the null hypothesis. The Kolmogorov-Smirnov tests between each RCM past and future scenario show a high level of significance $(p \approx 0)$, meaning that the projected changes in the future flood level distributions are statistically significant. For example, the projected changes in the cumulative distribution functions (CDFs) for the MPI-ESM-LR RCM across RCP2.6, RCP4.5 and RCP8.5 emission scenarios at Coole turlough are shown in Fig. 4. A marked shift to the right is seen in the distribution above flood levels (stage) of $5.5 \mathrm{~m}$ above (Irish) Ordnance Datum (mOD), with the RCP8.5 scenario showing the greatest shift, with similar shifts in magnitude predicted for both the low and medium emission scenarios. This indicates the likelihood of higher flood levels being observed is higher in all future emission scenarios.

The predicted shifts in the data are further illustrated using box plots, as shown in Fig. 5 for Cahermore turlough. In general, the RCMs predict progressively higher median and 75th percentile flood levels with higher emission scenarios, with a few exceptions. The HADGEM2-ES and MIROC5 RCMs predict similar future medians to the past, albeit with increased 75th percentiles, whilst the MIROC5 results actually predict lower future 25 th percentile flood levels. Extreme values for all RCM future scenarios are increased, with the exception of the RCP4.5 emission scenario for the MIROC5 $\mathrm{RCM}$. The reason for variation between various model results is linked to the factors which impact karst flooding (e.g. which season, dry or wet event impacts, winter vs. summer,

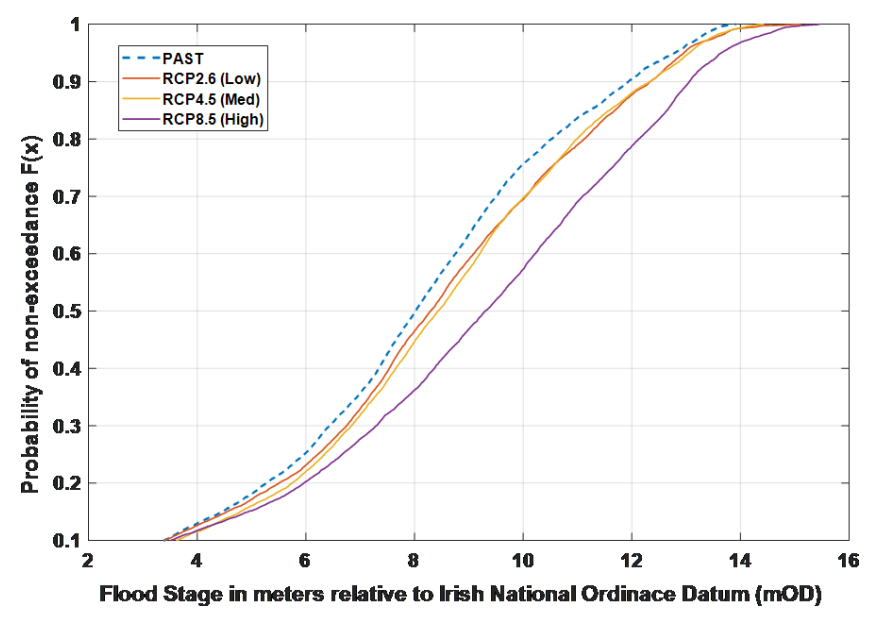

Figure 4. Comparison of the non-parametric cumulative distribution function (CDF) plots for the past and future RCM scenarios using the MPI-ESM-LR GCM data sets at Coole turlough. The $y$ axis shows the probability $F(x)$ of a particular flood stage (mOD) being less than or equal to $x$. Note that Coole turlough is one of the key turloughs in the region and is representative of others throughout the catchment.

evapotranspiration vs. precipitation, etc.). The karst system responds to previous cumulative rainfall along with existing flood level, so the pattern of rainfall is crucial to the level and extent of flooding. Given that the GCM and RCM data are randomised, the response of the karst model to the varying inputs will range. The use of ensembles mitigates this potential area of uncertainty and gives a better indication of likely future scenarios.

The Wilcoxon rank sum test was employed to test for the statistical significance of projected changes in median flood levels. The Wilcoxon rank sum tests the null hypothesis that the past and future data are from continuous distributions with equal medians against the alternative that they are not. Each of the Wilcoxon rank sum tests showed a high level of significance $(p \approx 0)$ for the all ensemble scenarios across the entire catchment, which therefore indicates that the projected changes in the future flood level distributions and medians are statistically significant.

\subsection{Implications for mean and recurrent flood levels and ecohydrology}

In order to estimate the likely magnitude of change in future flood levels, an examination of mean flood levels across the catchment was undertaken. Table 3 summarises the ensemble average percentage change in sample means for all RCM scenarios across the catchment. The models predict that ensemble mean flood levels will increase by an average $3.5 \%$ for the low emission scenario and by $7.9 \%$ in the high emission scenario across the catchment. Increases in mean water levels indicate either an increase in the magnitude of flood levels as a whole or an increase in the durations of flooding 
MPI-ESM-LR
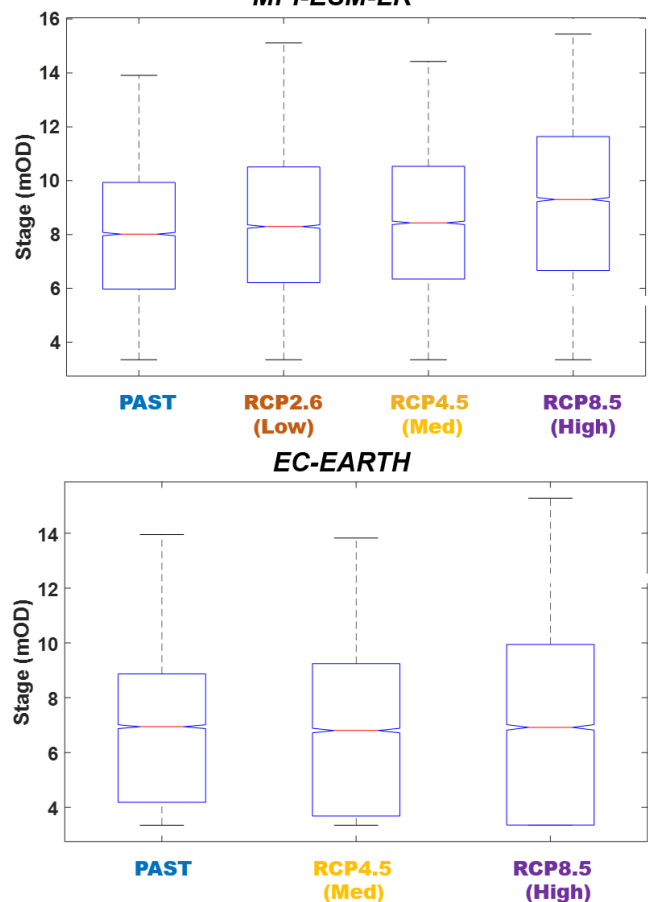

CNRM-CM5

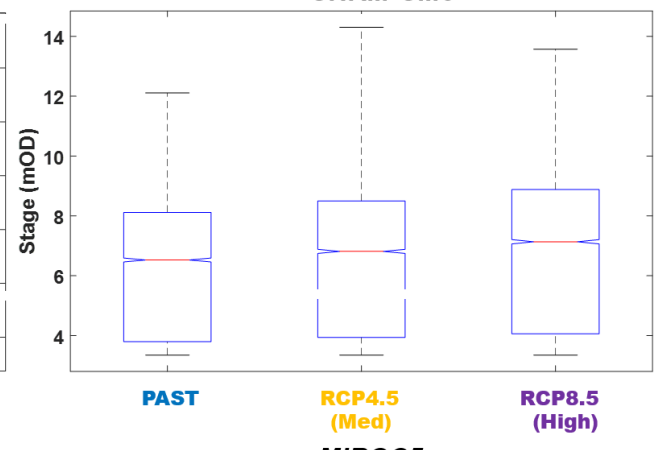

MIROC5

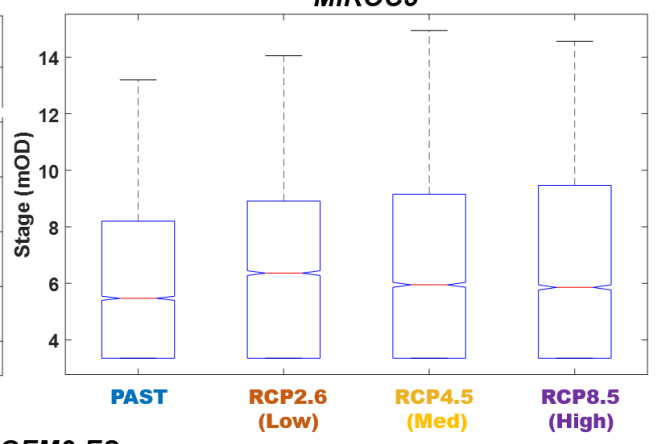

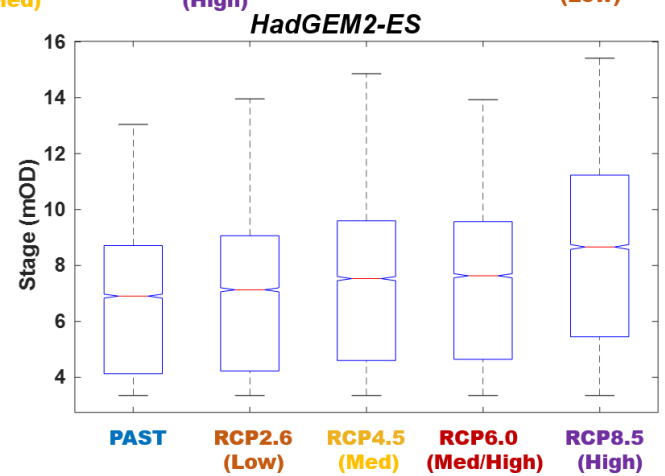

Figure 5. Box plots of model results for each of the RCMs, showing past and future RCM scenarios at Cahermore turlough. The central mark (red) indicates the median, and the bottom and top edges of the box indicate the 25 th and 75 th percentiles, respectively. Note that Cahermore turlough is one of the key turloughs in the catchment and is therefore representative of the general catchment trends.

at higher elevations (or both). Further analysis below reveals the nature of such mean flood level increases in more detail.

The impact of climate change on the seasonality of flooding in the turloughs was also examined using the simulated climate data. The seasonality of flooding at turloughs typically follows a pattern over the hydrological year (OctoberSeptember), whereby flooding commences in October or November, with peak flood levels observed anywhere between October and February. Figure 6 illustrates the ensemble shift in the seasonality of flooding predicted to occur for the low, medium and high emission scenarios. The historical data set shows the peak frequency of flood levels generally occurring over the months from December to February. Each of the future RCM scenarios predict these frequencies will shift significantly towards January and February and on into March for the high emission scenario. The implications of peak flooding occurring later in the hydrological year (i.e. January and February) are likely to mean flooding persisting later into late spring and even early summer, as it usually takes a number of months for flood waters to drain down. This is especially significant for extreme flood events when a peak event occurring in late February could see flood water persisting until mid or late May. The associated impact on ecological habitats and indeed on farming (flooded lands adjacent to turloughs) in the catchment from this seasonal shift could be significant as persistent flooding could impact the growing season for wet grasslands and floral species. The impact of the timing of such peak events was demonstrated in the catchment during the two most recent extreme events. The extreme event that occurred in 2009 peaked in late November, and flood waters were largely abated by midMarch 2010; however, flood waters from the extreme event 
Table 3. Ensemble average percentage change in sample means for all RCM scenarios at all groundwater flood nodes within the South Galway karst model domain (a positive value indicates an increase in mean annual water level within the hydrological year).

\begin{tabular}{lrrrr}
\hline \multirow{2}{*}{$\begin{array}{l}\text { Location within } \\
\text { catchment }\end{array}$} & \multicolumn{4}{c}{$\begin{array}{c}\text { Ensemble average percent change } \\
\text { in mean flood level }\end{array}$} \\
\cline { 2 - 5 } & $\mathrm{RCP} 2.6$ & $\mathrm{RCP} 4.5$ & $\mathrm{RCP} 6.0$ & $\mathrm{RCP} 8.5$ \\
\hline Ballinduff & 1.29 & 1.11 & 2.01 & 2.10 \\
Ballylea & 1.67 & 1.68 & 2.72 & 3.75 \\
Ballyloughaun & 0.14 & 0.21 & 0.18 & 0.60 \\
Blackrock & 3.83 & 4.12 & 6.30 & 8.98 \\
Caherglassaun & 8.14 & 8.29 & 12.20 & 17.62 \\
Cahermore & 5.61 & 7.01 & 9.75 & 15.42 \\
Castletown & 2.42 & 2.86 & 3.94 & 6.86 \\
Coole & 6.39 & 5.79 & 9.32 & 12.45 \\
Corker & 0.32 & 0.41 & 0.41 & 1.23 \\
Coy & 2.53 & 2.22 & 3.75 & 4.48 \\
Garryland & 7.32 & 7.72 & 11.78 & 16.48 \\
Hawkhill & 5.35 & 5.03 & 7.19 & 9.88 \\
Kiltartan & 1.25 & 1.44 & 1.86 & 3.80 \\
Mannagh & 0.82 & 0.87 & 1.51 & 1.94 \\
Newtown & 5.67 & 5.57 & 8.96 & 12.26 \\
Catchment average & 3.52 & 3.62 & 5.46 & 7.86 \\
\hline
\end{tabular}

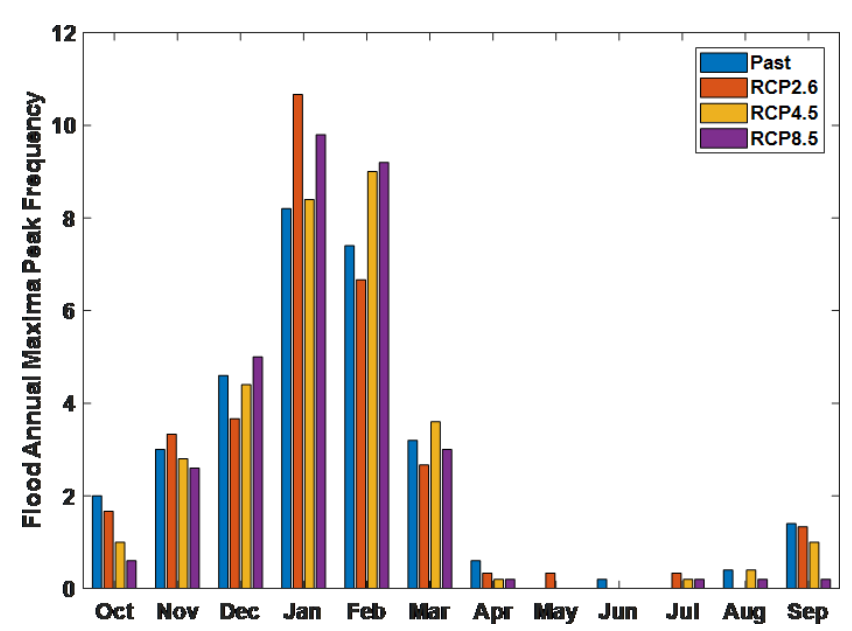

Figure 6. Bar chart illustrating the seasonal shift in frequencies of peak annual flood levels at Coole turlough over the hydrological year for all future RCM scenarios (with RCP6.0 omitted). Note that Coole turlough is one of the key turloughs in the catchment and is therefore representative. The $y$ axis shows the number of times (or frequency) when the annual maximum peak flood level occurred during each month of the year for the RCP ensembles.

of 2015-2016, which peaked in January 2016, persisted until late April 2016.

The spatial distribution of different vegetation communities in such wetlands is intimately entwined with the hydrological conditions (flood duration, flood depth, time of year of flood recession, etc.), which change on a gradient mov- ing up from the base of the turloughs. These ecohydrological relationships have been researched in multidisciplinary studies on these turloughs, investigating links between the fluctuating hydrological regime and vegetation habitats, invertebrates, soil properties, land use and water quality (Kimberley et al., 2012; Irvine et al., 2018; Waldren et al., 2015), from which metrics have then be defined for the different key wetland habitats. For example, recent ecohydrological analysis of the spatial distribution of vegetation habitats on four turloughs in this karst network (Blackrock, Coy, Garryland and Caherglassaun) over a 28-year period has revealed distinct differences between vegetation communities, from Eleocharis acicularis found at the base of the turlough, typically experiencing 6 to 7 months of inundation per year, compared to the limestone pavement community at the top fringes of the turloughs, which are only flooded from 1 to 2 months per year (see Fig. 7). These differences in flood depth and duration are also reflected in a gradient of times across the early growing season (spring) when the communities emerge from the flood waters (and associated changes in air temperature and solar radiation). Other investigations on invertebrates in the turloughs (Porst and Irvine, 2009; Porst et al., 2012) have shown that hydroperiod (flood duration) has a significant effect on macroinvertebrate taxon richness, with short hydroperiods supporting low faunal diversity. The study demonstrates how different colonisation cycles occur in response to the seasonal hydrological disturbances (see Fig. 8).

The duration of inundation at various flood levels is of extreme importance, both from an ecological perspective in terms of wetland species distribution and survival and for extreme flooding in terms of the disruption to homes, transport links and agricultural land inundated by flood waters. An examination of the flood-duration curves across each of the five RCP scenarios (see Fig. 9) indicates moderate to significant changes in the patterns of flood duration across the catchment. The MIROC5 RCM predicted the highest upward shift in flooded durations, with a projected catchment average 99th percentile increase of $1015 \%$. The EC-Earth RCM predicts a reduction in low flood level durations and an increase in high flood durations, with all other models generally predicting no significant shift in low to medium flood levels but upward shifts in flood durations at higher levels. Whilst the medium to low flood levels, which tend to be of more importance with respect to ecohydrology, appear to be relatively unaffected, an examination of the more frequent flood inundation recurrences was undertaken using annual exceedance probabilities (AEPs). The 50\%, $20 \%$ and $10 \%$ AEP flood levels were estimated for both the past and future scenarios using extreme value distributions. Given that the past and future horizons cover 30-year periods, it was possible to estimate the $10 \%$ AEP flood level with relative confidence. The annual maximum flood level series (using the hydrological year from October to September) was extracted for each past and future scenario, and an extreme value statistical distribution was fit- 

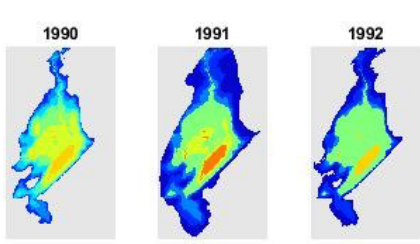

Yearly mean duration under flood 1989 - 2017
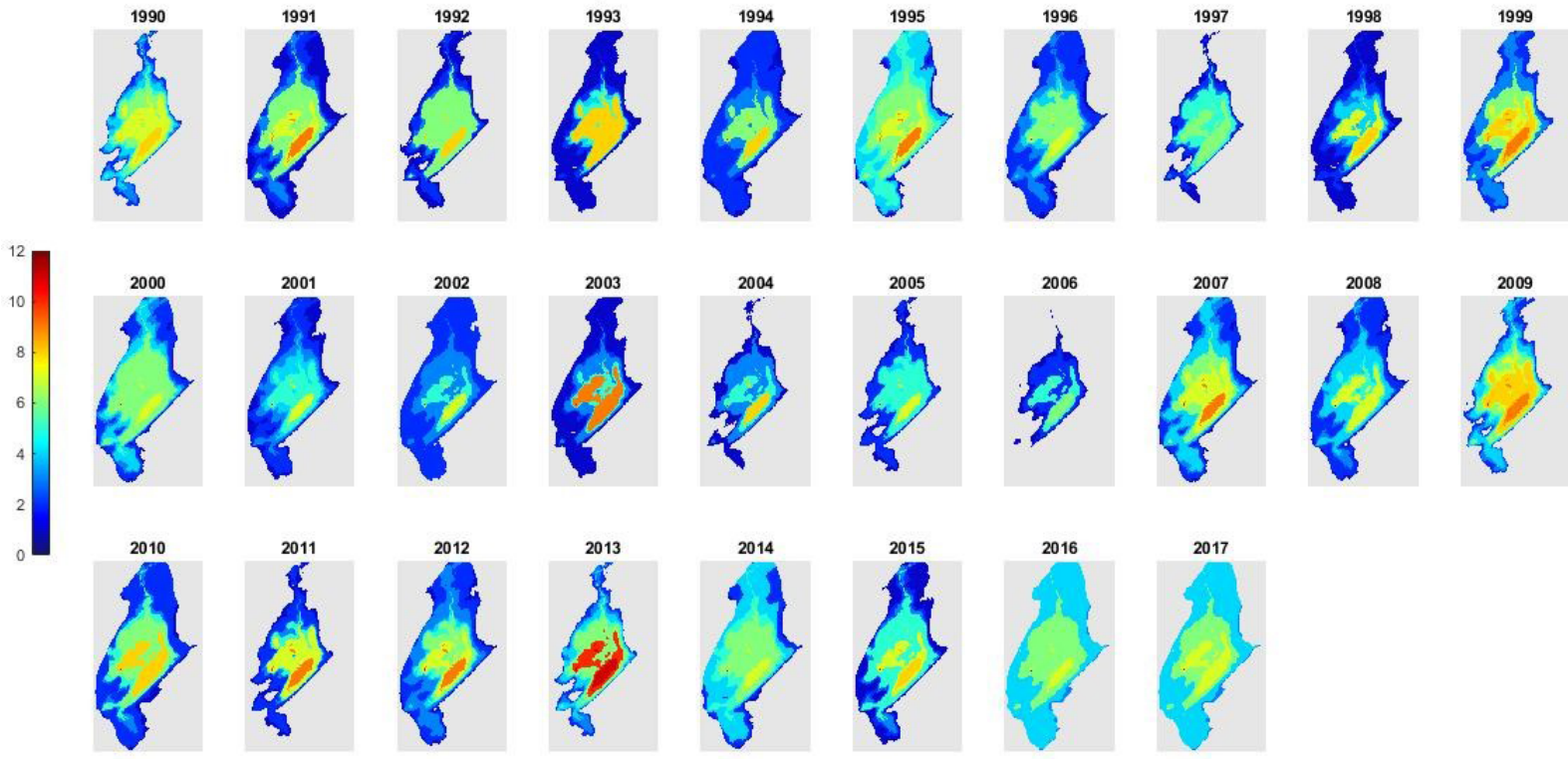

Figure 7. Annual flood duration spatial profiles for Blackrock turlough over a 28-year period (Bhatnagar et al., 2021).

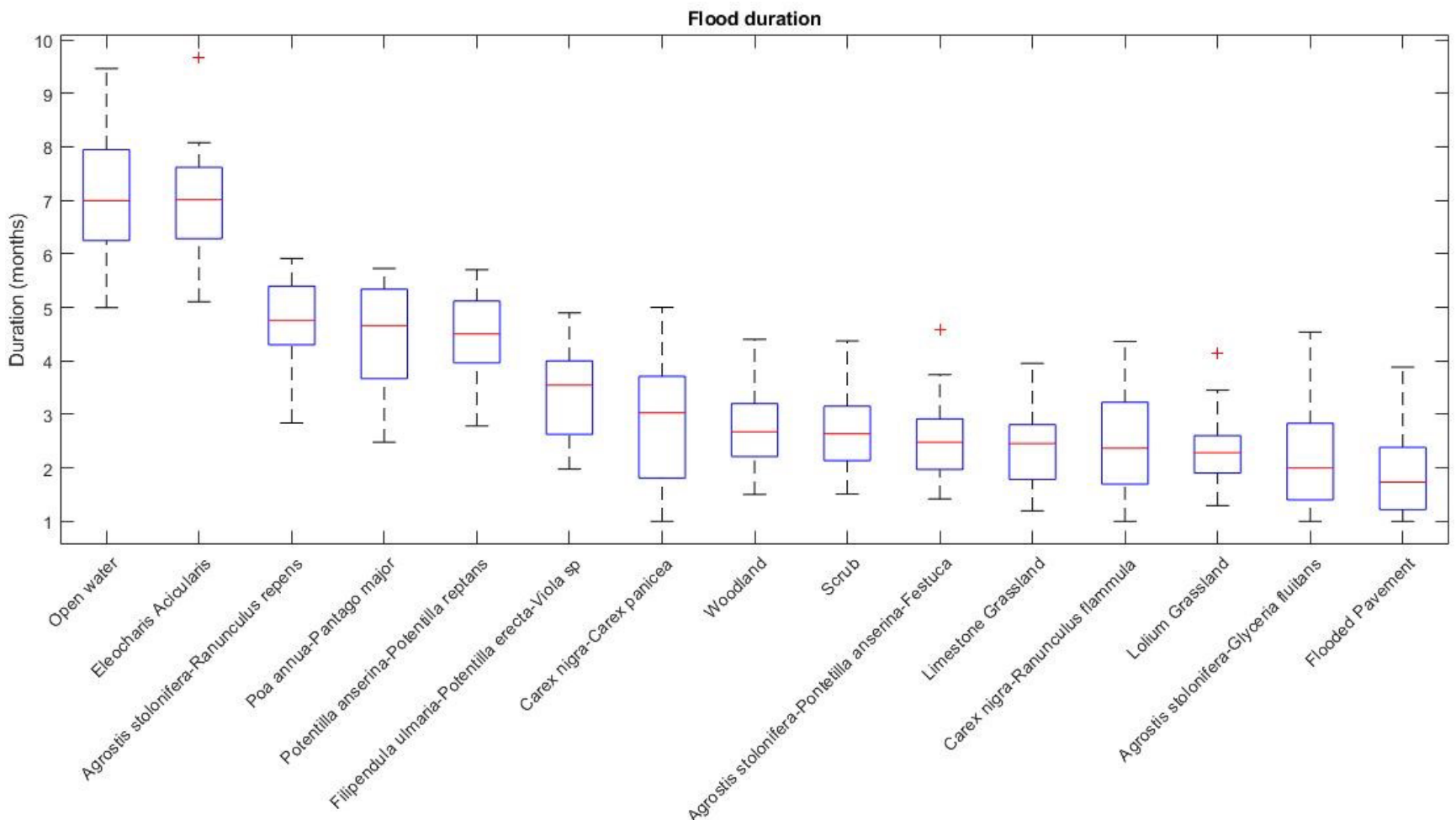

Figure 8. The statistics of flood duration as a metric across the range of turlough vegetation communities, averaged over four turloughs, over a 28-year period (Bhatnagar et al., 2021). 
Table 4. Ensemble catchment average percentage change in $50 \%$, $20 \%$ and $10 \%$ annual exceedance probability (AEP) flood levels for all RCM scenarios (a positive value indicates an increase in mean annual water level within the hydrological year).

\begin{tabular}{lrrr}
\hline RCM Scenario & \multicolumn{3}{c}{$\begin{array}{c}\text { Ensemble average percent change } \\
\text { in AEP flood level }\end{array}$} \\
\cline { 2 - 4 } & $50 \%$ AEP & $20 \%$ AEP & $10 \%$ AEP \\
\hline RCP2.6 & 2.92 & 3.88 & 4.25 \\
RCP4.5 & 4.52 & 5.63 & 6.05 \\
RCP6.0 & 4.67 & 4.60 & 4.58 \\
RCP8.5 & 8.97 & 9.76 & 10.07 \\
\hline
\end{tabular}

ted to the data. Each of the relevant flood levels were then estimated using the distributions, and for each RCM, the future and past values were compared to assess the projected future changes. The resultant ensemble catchment average changes in $50 \%, 20 \%$ and $10 \%$ AEP flood levels across the various RCPs are shown in Table 4 . The models predict a $4 \%$ increase in the $10 \%$ (10-year return period) AEP flood level for the low emission scenario and $10 \%$ increase in the high emission scenario. Similar increases are observed for the more frequent flood events, indicating flooding of the turloughs will become more regular, even at lower levels with the duration of dry or empty periods reduced. Given that the topography of each turlough basin varies widely (i.e. steep versus shallow sides), a $10 \%$ increase in lower flood levels will generally not be dramatic in terms of groundwater flooding with respect to the risk to properties and/or damage and disruption throughout the catchment, but it will impact a large area as the side gradients tend to be shallow closer to the turlough bases. These changes in flood durations and the recurrence of flooding outside of the determined ecohydrological metric envelopes will undoubtedly have significant impacts for turlough ecohydrology.

When assessing the impacts of climate on groundwater flooding in the lowland karst of Ireland, the extreme values within the data are of most interest. Given that the future horizon considered for all scenarios covers the 30 -year period between 2071-2100, this is not a long enough period from which to estimate the $1 \%$ AEP with any degree of certainty. In addition, due to the non-parametric nature of the data, it was not possible to employ the use of extreme value statistical distribution to estimate values without introducing large margins of error. For example, the peak values between the past and future scenarios were found to vary between $-1.6 \%$ and $+16.5 \%$ across each of the various future RCM scenarios; however, there is no statistical test to determine if these changes are indicative of a trend or linked to random chance within a 100-year future time interval. Trends in the 95th and 99th percentile time series values have previously been used successfully to test for statistically significant trends in extreme values in climate change analysis (Franzke, 2013). In order to establish if a statistically significant difference existed in the future RCM scenarios, the Kolmogorov-Smirnov two sample test was therefore used, with all values below the 95th percentile excluded.

The null hypothesis was rejected for all future RCM scenarios, indicating that the differences between the distributions in the upper (and most extreme) range are statistically significant. Sample CDF plots of past and future scenarios for the MPI-ESM-LR RCM at Coole turlough, utilising data values above the 95th percentile, are given in Fig. 10.

Given that this test indicates that a future trend exists, the 95th and 99th percentile values at each model node were then calculated for each of the ensemble RCM simulations, and the ensemble average percentage change between each of the past and future scenarios was used to determine the ensemble average across the entire catchment (see Table 5). All future scenarios predict an increase in the $95 \%$ percentile flood level across each model node, with the catchment average ranging between $+3.8 \%$ (future low) and $+10.3 \%$ (future high). It must be noted that two of the turloughs in the catchment (Ballinduff and Coy) show very little change in 95th percentile values across all future scenarios. Both of these turloughs are almost always permanently flooded, with Ballinduff having a relatively narrow range of annual fluctuation in flood levels $(<4 \mathrm{~m})$. Both locations flood to their notional maximum level far more frequently, with further increases in flood water levels controlled by either overland flow paths or sinkholes at higher elevations. This is not representative of the majority of other flood locations within the catchment, which reach their notional maximum flood levels far less frequently. Hence, it should be noted that removing these two turloughs from this analysis would only serve to further increase the catchment average values shown in Table 5 .

A further calculation was then undertaken which estimated the percent change in the frequency of days with peak flood levels greater than the current 95th and 99th percentiles, respectively. The simulations project $64 \%$ to $205 \%$ increases for the 95th percentiles across the RCM scenarios, with $171 \%$ to $621 \%$ increases in 99th percentile exceedance frequencies. That is, flood levels that are currently considered unusually high will become much more common. Given that mean flood levels across the catchment were also shown to increase by between $3.5 \%$ to $7.9 \%$, it follows that an upward shift in the more extreme flood levels (i.e. $1 \%$ AEP) will also occur. Whilst this analysis indicates that an increase in $1 \%$ AEP flood levels across the catchment will likely occur, the magnitude of the increase will be controlled by the natural overland spill points between the turloughs and also the capacity of potential linked overland flow paths to the sea.

The spatial extent of the $1 \%$ AEP flood for the study catchment was carried out and compared to a similar map produced for the same flood using the RCP4.5 (med) ensemble results (see Fig. 11). The $1 \%$ AEP flood predicts that $24.18 \mathrm{~km}^{2}$ will be flooded during the peak. This compares 
Implications for extreme flood events
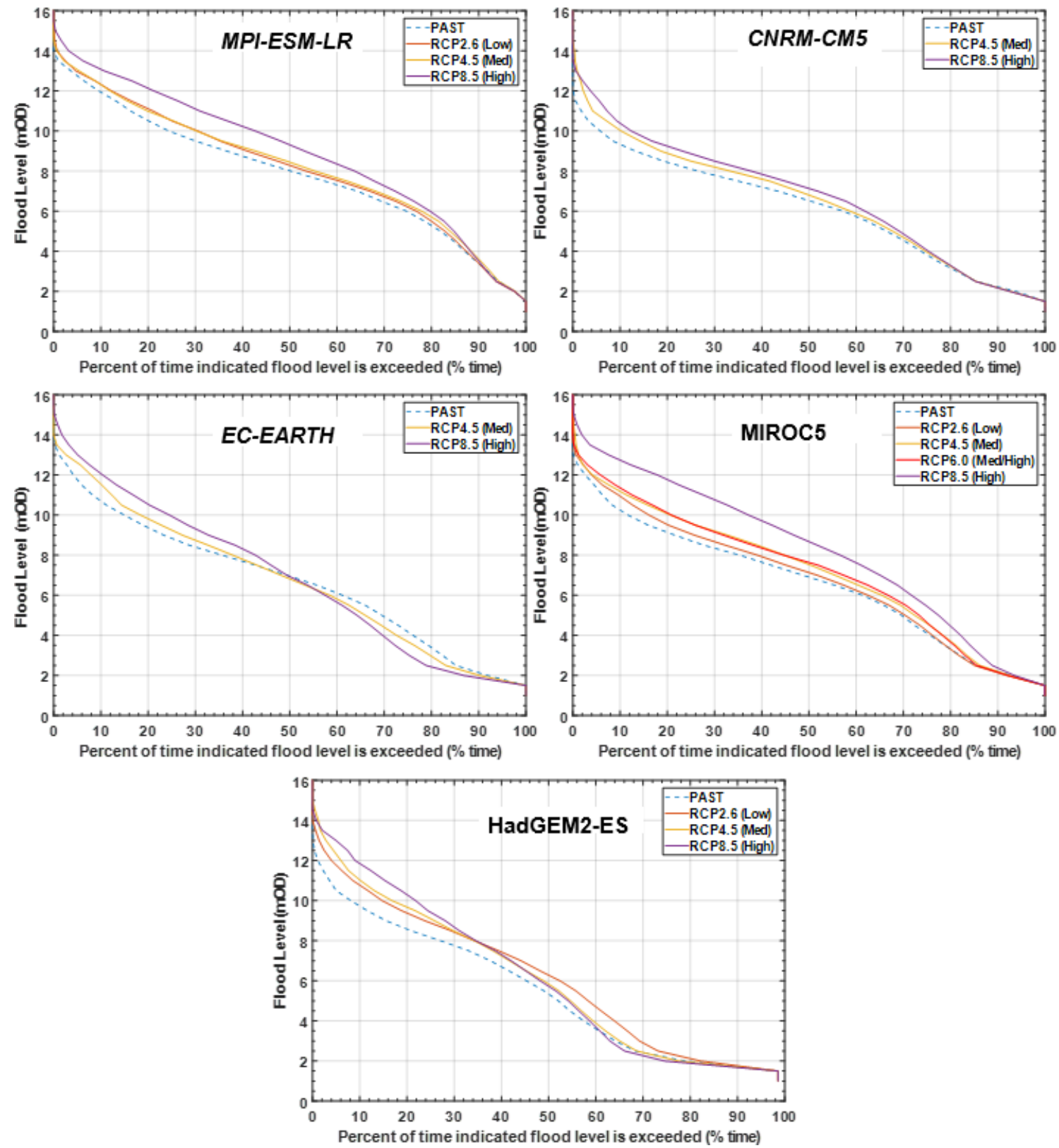

Figure 9. Flooded duration curves at Coole turlough for each of the RCM scenarios.

to $29.77 \mathrm{~km}^{2}$ inundated during the RCP4.5 (med) scenario (a $23 \%$ increase). It must be noted that Fig. 11 only includes the food extents of the subject model, and flooding from other sources (not simulated) would also likely occur during such an event.

\subsubsection{Impact of rising mean tide levels}

All 19 future RCM scenarios were re-simulated with the downstream tidal boundary condition increased to reflect projected rises in mean sea level. The tidal boundary sig- nals used in the future RCM scenarios were therefore shifted upwards by 0.55 and $1.05 \mathrm{~m}$, respectively, and all future scenarios were re-assessed. No statistically significant change in any of the resulting distributions was found, however, when compared to the future RCM scenarios with no sea level increases. This indicates that the differences between the distributions with mean sea level increases are statistically insignificant, and that rises in mean sea levels of up to $1.05 \mathrm{~m}$ will have little impact in this karst catchment over and above the impacts of changing climate. Similarly, there was no appreciable change in average or 95th percentile flood levels 
Table 5. Ensemble percentage change in 95th percentile flood levels for all RCM scenarios at all groundwater flood nodes within the South Galway karst model domain (a positive value indicates an increase in 95th percentile water level within the hydrological year).

\begin{tabular}{lrrrr}
\hline Location within catchment & \multicolumn{4}{c}{ Ensemble average } \\
\cline { 2 - 5 } & RCP2.6 & RCP4.5 & RCP6.0 & RCP8.5 \\
\hline Ballinduff & 0.05 & 0.06 & 0.06 & 0.11 \\
Ballylea & 2.19 & 2.63 & 3.43 & 7.97 \\
Ballyloughaun & 0.51 & 1.74 & 1.53 & 4.78 \\
Blackrock & 3.87 & 4.93 & 5.73 & 10.51 \\
Caherglassaun & 5.84 & 6.99 & 6.88 & 17.09 \\
Cahermore & 5.84 & 7.47 & 7.14 & 16.65 \\
Castletown & 5.65 & 7.76 & 7.73 & 14.31 \\
Coole & 5.74 & 7.87 & 7.67 & 14.80 \\
Corker & 3.27 & 3.57 & 6.27 & 7.56 \\
Coy & 0.31 & 0.73 & 0.38 & 0.89 \\
Garryland & 5.74 & 7.41 & 7.60 & 15.03 \\
Hawkhill & 5.74 & 7.88 & 7.67 & 14.80 \\
Kiltartan & 5.32 & 6.33 & 6.08 & 11.33 \\
Mannagh & 1.25 & 2.24 & 2.59 & 3.66 \\
Newtown & 5.74 & 7.50 & 7.67 & 14.80 \\
Catchment average & 3.80 & 5.01 & 5.23 & 10.29 \\
\hline
\end{tabular}

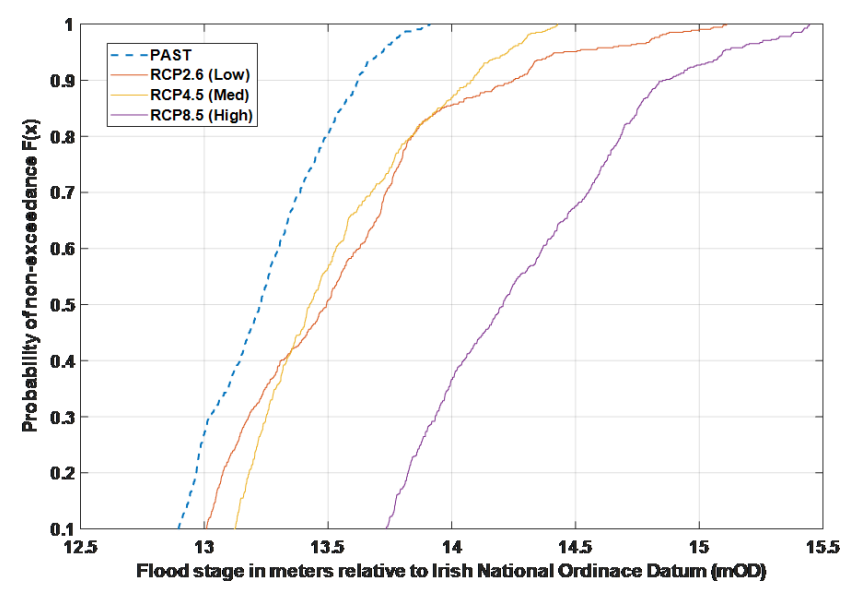

Figure 10. Comparison of the non-parametric cumulative distribution function (CDF) plots for the past and future RCM emission scenarios using the MPI-ESM-LR RCM data sets at $h$ values below the 95th percentile excluded (annual maxima levels).

across the catchment $(<0.05 \mathrm{~m})$. Minor changes in peak levels $(<3 \%)$ were observed at Caherglassaun turlough, which is the closest to the sea and where a tidal signal is observed at low flood stages; this minor change, however, was not observed at any other location. The observed changes at $\mathrm{Ca}$ herglassaun were not enough to reject the null hypothesis for any statistical test. An examination of the pattern of outflows from the system at the springs at Kinvara confirms that these results are to be expected. The majority of outflow from the system (through the intertidal springs) occurs during the ebb tide when the bay is essentially empty (elevation $<-2.5 \mathrm{mOD}$ ) or emptying. Even a mean sea level rise of $1.05 \mathrm{~m}$ would only increase the bottom elevation of the ebb tide to approximately $-1.5 \mathrm{mOD}$, which would still allow equivalent volumes of water to drain from the system during ebb tide. In addition, an examination of the spring outflows for the historical and future RCP scenarios through the ebb or flood tidal cycle showed water was still flowing out of the system as the tide rises due to the pressure head between groundwater in the aquifer (and the turloughs) and the springs.

A comparison was made between the findings of this study and other karst studies which considered climate change. A study undertaken by Nerantzaki and Nikolaidis (2020) was similar in nature (i.e. use of GCM and RCM data with karst models) and indicated that a reduction in karst spring flow of between $14 \%$ and $25 \%$ could occur under climate change scenarios (the authors used a blended rainfall spectrum from RCP2.6 and RCP8.5). This range is comparable to some of the results observed in this study. Similarly, other studies focused on the impacts of karst aquifers due to climate change utilise GCM/RCM and various emissions scenarios (Pardo-Igúzquiza et al., 2019) but are concerned with impacts on recharge (and spring water availability), and flooding/ecohydrology are not considered. It is, therefore, difficult to provide direct comparisons with this current study; however, the authors are confident that the projections reported in this study are broadly in line with other international studies. 


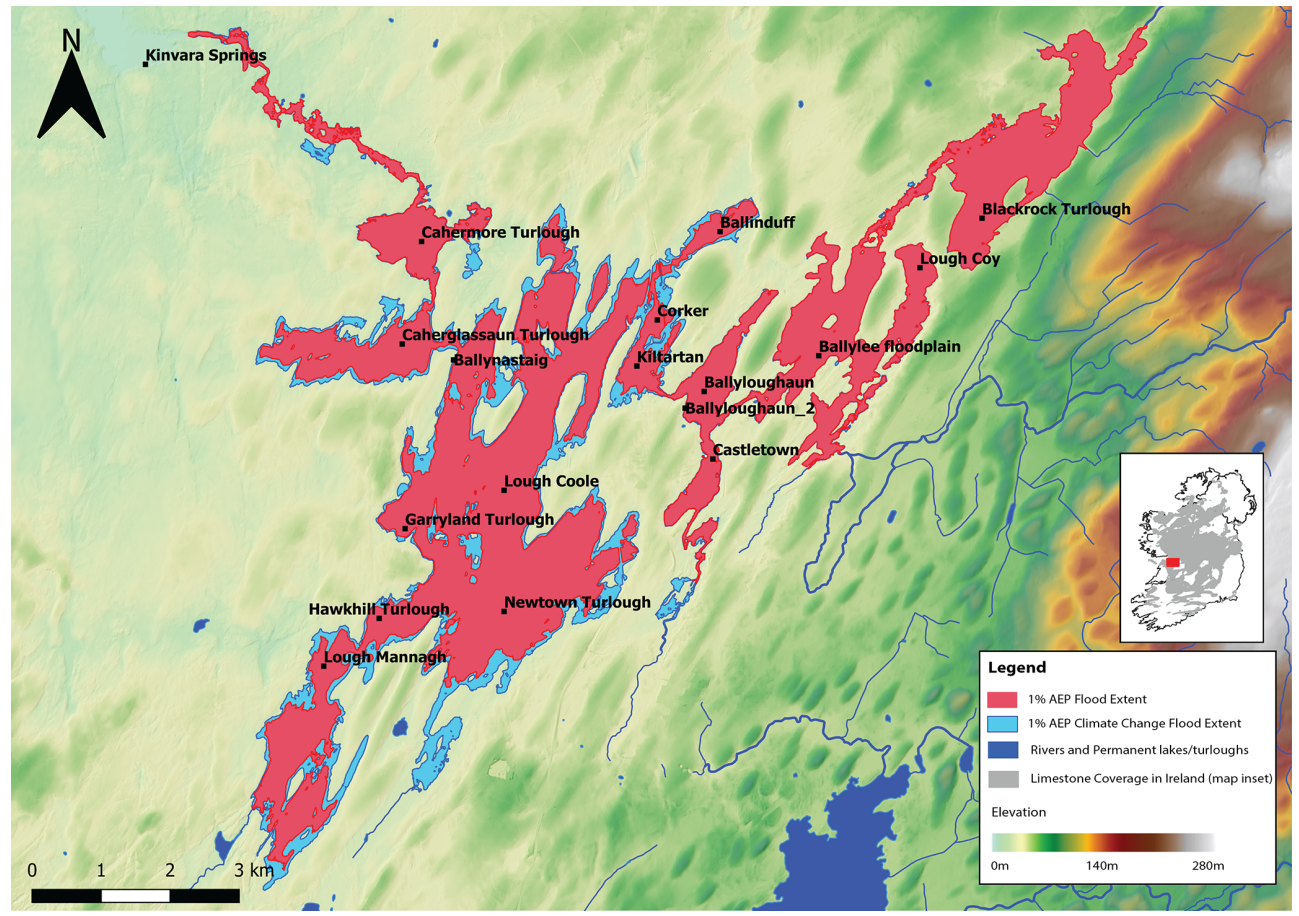

Figure 11. Comparison of the spatial extent of the $1 \%$ AEP flood event for the study catchment and the associated increases predicted during the RCP4.5 (medium) ensemble scenario. This figure contains Irish Public Sector Data (Geological Survey Ireland), licensed under a Creative Commons Attribution 4.0 International (CC-BY 4.0) licence.

\section{Conclusions}

\subsection{Groundwater flooding}

It has been established that the long-term trends of the lowland karst aquifer dynamics (e.g. spring discharge, groundwater levels and groundwater flooding) are affected by precipitation patterns (intensity and accumulation) over the preceding weeks and months leading up to peak water levels (peak flood events) that are typically late in the winter or early spring (Naughton et al., 2012). Quantifying the impact of changing rainfall patterns is therefore of utmost importance when considering future groundwater flood risk in such lowland karst catchments. Whilst significant variations in the magnitudes of predicted future increases in flood levels were observed in this study, the underlying trend in the RCM data simulated is predicting increases in mean annual flood levels (groundwater levels), 95th and 99th percentile levels and, most significantly, in flood durations, particularly at higher (and more extreme) flood levels. This study has demonstrated how the spatial extent of the $1 \%$ AEP flood will expand, which is useful for flood risk mapping purposes. Each of the various downscaled GCM data sets predicted statistically significant increases in all relevant flooding statistics and, notably, a shift in the seasonality of the flooding. This shift will likely compound the impact in the catchment given that the existing summer "dry" period may be curtailed. The pro- jected large increases in the frequencies of the existing (past) 99th percentile exceedances of up to $1015 \%$ clearly demonstrate that what is currently considered to be high or extreme flooding will become more of a regular occurrence in the future. In terms of planning for future development, or indeed developing flood alleviation projects for such lowland karst systems, being able to predict the projected changes in mean flood levels and extreme events will be vital in order to ensure that developments proceed with minimal risk to property or human life. In this study catchment, this could result in potential flood alleviation channels being sized to accommodate considerable larger flows than what may be considered sufficient based on current conditions. The implications of this study for similar karst catchments and climate zones with high recharge rates and significant seasonal variations in groundwater levels are equally significant and could also impact on other activities such as tunnelling and mining in such karst environments.

\subsection{Ecohydrology}

Ecosystems which rely on groundwater to sustain wetland conditions are particularly at risk of changes in inundation fluctuation regimes brought about by climate change. This study has shown that the pattern of flooding at turloughs in the west of Ireland is likely to change significantly with higher mean flood levels over longer durations. Different unique habitats have developed under such cyclical en- 
velopes of hydrological conditions, presenting a spatial gradient of different communities that can exist under the different conditions moving up from the base of the turlough. Hence, the results of this climate change study predict that a change in the hydrological regime is likely to cause associated changes in the location and extent of these habitat zones within turloughs. Furthermore, some of these habitats may be at threat due to the predicted shift in the seasonality of flooding to later in the hydrological year, causing a delay in the critical early growing season for wetland grasses and flora. Ongoing studies have been investigating the differences in prevailing air temperature and solar radiation for the vegetation communities across the turloughs as they come out of the winter flood regime at different times and are first exposed to air in the spring. The increase in more extreme events could also have a detrimental impact on fringing habitats which develop along the perimeter of these sites (typically woody shrubs and trees or limestone pavement communities), which would be severely impacted were they to become flooded on a more regular basis. An argument could be made that the habitat zones could simply be shifted upwards in elevation, essentially expanding the extent of the wetlands. However, given that turloughs are often located within defined basins, the room for their growth is constrained, and the loss of some habitat is likely to be unavoidable. For other, similar groundwater-dependent ecosystems in similar climate zones in karst, such as fens, the implications of fluctuations in future groundwater levels and flows are equally significant.

In the wider context, this study has shown that the use of complex transient groundwater models with the output from RCM models can provide specific and targeted information on the likely effects of climate change on groundwater levels, flooding and ecohydrology. More specifically, this methodology can clearly be transferred to study other karst-based GWDTEs such as calcareous fens and poljes.

Code availability. The karst model was developed within Infoworks ICM which is a Sewer, Storm and Flood Modelling package (see https://www.innovyze.com/en-us/products/infoworks-icm; Innovyze, 2019) which can be purchased from the developer. The model network itself is not publicly available as it has been developed as a unique sequence of pipes, channels and storage nodes to represent the catchment in south Galway. The process of the model development is described in detail in Gill et al. (2013).

Data availability. Turlough stage data used within this modelling exercise and the spatial mapping which resulted can be assessed from the Geological Survey of Ireland at https://www.gsi.ie/enie/publications/Pages/GWFlood-Project-Monitoring-Modellingand-Mapping-Karst-Groundwater-Flooding-in-Ireland.aspx (GSI, 2020) or by emailing groundwaterinfo@gsi.ie. Simulated future climatological data for Ireland used within this study are available from https://erddap.ichec.ie/erddap/files/EPA_Hydroclimate (ICHEC, 2020).
Author contributions. PM and LG designed this study. PN provided climatological data and assisted with statistical analysis. TM and ON assisted with the provision of observation data sets. PM performed model simulations, primary analysis and drafted the paper. PJ contributed to results interpretation and review of the paper. SB and TM assisted with the preparation of figures.

Competing interests. The authors declare that they have no conflict of interest.

Acknowledgements. This work was carried out as part of the scientific project "GWFlood: Groundwater Flood Monitoring, Modelling and Mapping" funded by Geological Survey Ireland and by the Galway County Council. The work also represents outputs from research funded by the Office of Public Works and the Irish Research Council. The authors would like to thank the Irish Meteorological Service (Met Éireann) for the provision of rainfall data, the Galway County Council for the provision of aerial photography and GIS data and the Office of Public Works for the provision of LIDAR, hydrometric and aerial photography data. The authors would also like to thank the two anonymous reviewers whose input and suggestions have added greatly to this paper.

Financial support. This project has been supported by the Geological Survey Ireland Groundwater Programme (contract no. 2016ExRP-GW-001) and by the Galway County Council (grant no. 16047).

Review statement. This paper was edited by Anke Hildebrandt and reviewed by two anonymous referees.

\section{References}

Ahilan, S., O’Sullivan, J. J., and Bruen, M.: Influences on flood frequency distributions in Irish river catchments, Hydrol. Earth Syst. Sci., 16, 1137-1150, https://doi.org/10.5194/hess-16-11372012, 2012.

Bhatnagar, S., Gill, L. W., Waldren, S., Sharkey, N., Naughton, O., Johnston, P., Coxon, C., Morrissey, P., and Ghosh, B.: Ecohydrological metrics for vegetation communities in turloughs (ephemeral karstic wetlands), Ecohydrology, in review, 2021.

Bieniek, P. A., Bhatt, U. S., Walsh, J. E., Rupp, T. S., Zhang, J., Krieger, J. R., and Lader, R.: Dynamical Downscaling of EraInterim Temperature and Precipitation for Alaska, J. Appl. Meteorol. Clim., 55, 635-654, 2016.

Blöschl, G., Hall, J., Viglione, A., Perdigão, R. A. P., Parajka, J., Merz, B., Lun, D., Arheimer, B., Aronica, G. T., Bilibashi, A., Boháč, M., Bonacci, O., Borga, M., Čanjevac, I., Castellarin, A., Chirico, G. B., Claps, P., Frolova, N., Ganora, D., Gorbachova, L., Gül, A., Hannaford, J., Harrigan, S., Kireeva, M., Kiss, A., Kjeldsen, T. R., Kohnová, S., Koskela, J. J., Ledvinka, O., Macdonald, N., Mavrova-Guirguinova, M., Mediero, L., Merz, R., Molnar, P., Montanari, A., Murphy, C., Osuch, M., Ovcharuk, 
V., Radevski, I., Salinas, J. L., Sauquet, E., Šraj, M., Szolgay, J., Volpi, E., Wilson, D., Zaimi, K., and Živković, N.: Changing Climate Both Increases and Decreases European River Floods, Nature, 573, 108-111 https://doi.org/10.1038/s41586-019-14956, 2019.

Brenner, S., Coxon, G., Howden, N. J. K., Freer, J., and Hartmann, A.: Process-based modelling to evaluate simulated groundwater levels and frequencies in a Chalk catchment in southwestern England, Nat. Hazards Earth Syst. Sci., 18, 445-461, https://doi.org/10.5194/nhess-18-445-2018, 2018.

Cavicchia, L. and von Storch, H.: The simulation of medicanes in a high-resolution regional climate model, Clim. Dynam., 39, 2273-2290, https://doi.org/10.1007/s00382-011-1220-0, 2012

Chen, Z., Hartmann, A., Wagener, T., and Goldscheider, N.: Dynamics of water fluxes and storages in an Alpine karst catchment under current and potential future climate conditions, Hydrol. Earth Syst. Sci., 22, 3807-3823, https://doi.org/10.5194/hess-223807-2018, 2018.

Cobby, D., Morris, S. E, Parkes, A., and Robinson, V.: Groundwater Flood Risk Management: Advances Towards Meeting the Requirements of the Eu Floods Directive, J. Flood Risk Manag., 2, 111-119, https://doi.org/10.1111/j.1753-318X.2009.01025.x, 2009.

Daloz, A., Camargo, S., Kossin, J., Emanuel, K., Jones, J., Kim, D., LaRow, T., Lim, Y.-K., Roberts, M., Vidale, P. L., Patricola, C., Scoccimarro, E., Shaevitz, D., Wang, H., Wehner, M., and Zhao, M.: Cluster Analysis of Downscaled and Explicitly Simulated North Atlantic Tropical Cyclone Tracks, J. Climatol., 28, 13331361, https://doi.org/10.1175/JCLI-D-13-00646.1, 2015.

Di Luca, A., Argueso, D., Evans, J., Elía, R., and Laprise, R.: Quantifying the Overall Added Value of Dynamical Downscaling and the Contribution from Different Spatial Scales, J. Geophys. Res.-Atmos., 121, 1575-1590, https://doi.org/10.1002/2015JD024009, 2016.

Donat, M. G., Leckebusch, G. C., Wild, S., and Ulbrich, U.: Benefits and Limitations of Regional Multi-Model Ensembles for Storm Loss Estimations, Clim. Res., 44, 211-225, 2010.

Dragoni, W. and Sukhija, B. S.: Climate Change and Groundwater: A Short Review, Geol. Soc. Spec. Publ., 288, 1-12, https://doi.org/10.1144/SP288.1, 2008.

Drew, D. P.: Hydrogeology of Lowland Karst in Ireland, Q. J. Eng. Geol. Hydrogeol., 41, 61-72, https://doi.org/10.1144/14709236/07-027, 2008.

Feser, F.: Enhanced Detectability of Added Value in Limited-Area Model Results Separated into Different Spatial Scales, Mon. Weather Rev., 134, 2180-2190, https://doi.org/10.1175/MWR3183.1, 2006.

Feser, F. and Barcikowska, M.: The Influence of Spectral Nudging on Typhoon Formation in Regional Climate Models, Environ. Res. Lett., 7, 014024, https://doi.org/10.1088/17489326/7/1/014024, 2012.

Feser, F., Rockel, B., von Storch, H., Winterfeldt, J., and Zahn, M.: Regional Climate Models Add Value to Global Model Data: A Review and Selected Examples, B. Am. Meteorol. Soc., 92, 1181-1192, https://doi.org/10.1175/2011bams3061.1, 2011.

Finch, J. W., Bradford, R. B., and Hudson, J. A.: The Spatial Distribution of Groundwater Flooding in a Chalk Catchment in Southern England, Hydrol. Process., 18, 959-971, https://doi.org/10.1002/hyp.1340, 2004.
Flanagan, J. and Nolan, P.: Towards a Definitive Historical Highresolution Climate Dataset for Ireland - Promoting Climate Research in Ireland, EPA Research 350, available at: https://www. epa.ie/pubs/reports/research/climate/researchreport350/, last access: 11 November 2020.

Flanagan, J., Nolan, P., McGrath, R., and Werner, C.: Towards a definitive historical high-resolution climate dataset for Ireland promoting climate research in Ireland, Adv. Sci. Res., 15, 263276, https://doi.org/10.5194/asr-15-263-2019, 2019.

Fleury, P., Ladouche, B., Conroux, Y., Jourde, H., and Dörfliger, N.: Modelling the Hydrologic Functions of a Karst Aquifer under Active Water Management - the Lez Spring, J. Hydrol., 365, 235-243, https://doi.org/10.1016/j.jhydrol.2008.11.037, 2009.

Ford, D. C. and Williams, P.: Karst Hydrogeology and Geomorphology, John Wiley, Chichester, 562, https://doi.org/10.1002/9781118684986, 2007.

Franzke, C.: A Novel Method to Test for Significant Trends in Extreme Values in Serially Dependent Time Series, Geophys. Res. Lett., 40, 1391-1395, https://doi.org/10.1002/grl.50301, 2013.

Gill, L. W., Naughton, O., and Johnston, P. M.: Modeling a Network of Turloughs in Lowland Karst, Water Resour. Res., 49, 34873503, https://doi.org/10.1002/wrcr.20299, 2013a.

Gill, L. W., Naughton, O., Johnston, P. M., Basu, B., and Ghosh, B.: Characterisation of Hydrogeological Connections in a Lowland Karst Network Using Time Series Analysis of Water Levels in Ephemeral Groundwater-Fed Lakes (Turloughs), J. Hydrol., 499, 289-302, https://doi.org/10.1016/j.jhydrol.2013.07.002, 2013b.

Gleeson, E., McGrath, R., and Treanor, M.: Ireland's Climate: The Road Ahead Met Éireann, Dublin, available at: http://hdl.handle. net/2262/71304 (last access: 8 May 2020), 2013.

Griffis, V. W. and Stedinger, J. R.: Log-Pearson Type 3 Distribution and Its Application in Flood Frequency Analysis. I: Distribution Characteristics, J. Hydrol. Eng., 12, 482-491, https://doi.org/10.1061/(ASCE)1084-0699(2007)12:5(482), 2007.

GSI: GW Flood Project Final Report \& Mapping, available at: https://www.gsi.ie/enie/publications/Pages/GWFlood-ProjectMonitoring-Modellingand-Mapping-Karst-GroundwaterFlooding-in-Ireland.aspx, last access: 2 December 2020.

Hartmann, Andreas.: Experiences in Calibrating and Evaluating Lumped Karst Hydrological Models, Geol. Soc. Spec. Publ., 466, 331, https://doi.org/10.1144/sp466.18, 2017.

Hartmann, A., Barberá, J., Lange, J., Andreo, B., and Weiler, M.: Progress in the Hydrologic Simulation of Time Variant Recharge Areas of Karst Systems - Exemplified at a Karst Spring in Southern Spain, Adv. Water Resour., 54, 149-160, https://doi.org/10.1016/j.advwatres.2013.01.010, 2013.

Howard, K. E. N. and Griffith, A.: Can the Impacts of Climate Change on Groundwater Resources Be Studied without the Use of Transient Models?, Hydrolog. Sci. J., 54, 754-764, https://doi.org/10.1623/hysj.54.4.754, 2009.

Hughes, A. G., Vounaki, T., Peach, D. W., Ireson, A. M., Jackson, C. R., Butler, A. P., Bloomfield, J. P., Finch, J., and Wheater, H. S.: Flood Risk from Groundwater: Examples from a Chalk Catchment in Southern England, J. Flood Risk Manag., 4, 143155, https://doi.org/10.1111/j.1753-318X.2011.01095.x, 2011.

ICHEC: EPA Hydroclimate Data, available at: https://erddap.ichec. ie/erddap/files/EPA_Hydroclimate, last access: 10 April 2020. 
Innovyze: Infoworks ICM Software, available at: https: //www.innovyze.com/en-us/products/infoworks-icm (last access: 15 May 2020), 2019.

IPCC, Climate Change 2013: The Physical Science Basis, Contribution of Working Group I to the Fifth Assessment Report of the Intergovernmental Panel on Climate Change, edited by: Stocker, T. F., Qin, D., Plattner, G.-K., Tignor, M., Allen, S. K., Boschung, J., Nauels, A., Xia, Y., Bex, V., and Midgley, P. M., Cambridge University Press, Cambridge, United Kingdom and New York, NY, USA, 1535 pp., 2013.

Irvine, K., Coxon, C., Gill, L., Kimberley, S., and Waldren, S.: Turloughs (Ireland), in: The Wetland Book, edited by: Finlayson, C. M., Milton, G., Prentice, R., and Davidson, N., Springer, Dordrecht, 1069-1077, 2018.

Jackson, C. R., Bloomfield, J. P., and Mackay, J. D.: Evidence for changes in historic and future groundwater levels in the UK, Progress in Physical Geography: Earth and Environment, 39, 4967, https://doi.org/10.1177/030913331455066, 2015.

Kanada, S., Nakano, M., Hayashi, S., Kato, T., Nakamura, M., Kurihara, K., and Kitoh, A.: Reproducibility of Maximum Daily Precipitation Amount over Japan by a HighResolution Non-Hydrostatic Model, SOLA, 4, 105-108, https://doi.org/10.2151/sola.2008-027, 2008.

Kanamaru, H. and Kanamitsu, M.: Fifty-Seven-Year California Reanalysis Downscaling at $10 \mathrm{Km}$ (Card10). Part Ii: Comparison with North American Regional Reanalysis, J. Climate, 20, 55725592, https://doi.org/10.1175/2007JCLI1522.1, 2007.

Kendon, E., Roberts, N., Senior, C., and Roberts, M.: Realism of Rainfall in a Very High-Resolution Regional Climate Model, J. Climate, 25, 5791-5806, https://doi.org/10.1175/JCLI-D-11$00562.1,2012$.

Kendon, E., Roberts, N., Fowler, H., Roberts, M., Chan, S., and Senior, C.: Heavier Summer Downpours with Climate Change Revealed by Weather Forecast Resolution Model, Nat. Clim. Change, 4, 570-576, https://doi.org/10.1038/nclimate2258, 2014.

Kimberley, S., Naughton, O., Johnston, P. M., Gill, L. W., and Waldren, S.: The influence of flood duration on the surface soil properties and grazing management of karst wetlands (turloughs) in Ireland, Hydrobiologia, 692, 29-40, https://doi.org/10.1007/s10750-012-1000-9, 2012.

Lucas-Picher, P., Wulff-Nielsen, M., Christensen, J. H., Aðalgeirsdóttir, G., Mottram, R., and Simonsen, S. B.: Very High Resolution Regional Climate Model Simulations over Greenland: Identifying Added Value, J. Geophys. Res.-Atmos., 117, https://doi.org/10.1029/2011jd016267, 2012.

Mayaud, C., Gabrovšek, F., Blatnik, M., Kogovšek, B., Petrič, M., and Ravbar, N.: Understanding Flooding in Poljes: A Modelling Perspective, J. Hydrol., 575, 874-889, https://doi.org/10.1016/j.jhydrol.2019.04.092, 2019.

McGrath, R. and Lynch, P.: Ireland in a Warmer World: Scientific Predictions of the Irish Climate in the Twenty-first Century, Community Climate Change Consortium for Ireland (C4I), available at: https://www.epa.ie/pubs/reports/research/climate/EPA_ climate_change_regional_models_ERTDI36.pdf (last access: 11 November 2020), 2008.

McGrath, R., Nishimura, E., Nolan, P., Semmler, T., Sweeney, C., and Wang, S.: Climate Change: Regional Climate Model Predictions for Ireland, Final Project Report published by the Environ- mental Protection Agency at: http://epa.ie/pubs/reports/research/ climate/EPA_climate_change_regional_models_ERTDI36.pdf (last accessed: 8 May 2020), 2005.

Meixner, T., Manning, A. H., Stonestrom, D. A., Allen, D. M., Ajami, H., Blasch, K. W., Brookfield, A. E., Castro, C. L., Clark, Jordan F., Gochis, D. J., Flint, A. L., Neff, K. L., Niraula, R., Rodell, M., Scanlon, B. R., Singha, K., and Walvoord, M. A.: Implications of Projected Climate Change for Groundwater Recharge in the Western United States, J. Hydrol., 534, 124-138, https://doi.org/10.1016/j.jhydrol.2015.12.027, 2016.

Morris, J., Bailey, A. P., Lawson, C. S., Leeds-Harrison, P. B., Alsop, D., and Vivash, R.: The Economic Dimensions of Integrating Flood Management and AgriEnvironment through Washland Creation: A Case from Somerset, England, J. Environ. Manage., 88, 372-381, https://doi.org/10.1016/j.jenvman.2007.03.023, 2008.

Morrissey, P. J., McCormack, T., Naughton, O., Johnston, P. M., and Gill, L. W.: Modelling Groundwater Flooding in a Lowland Karst Catchment, J. Hydrol., 580, 124361, https://doi.org/10.1016/j.jhydrol.2019.124361, 2020.

Moss, R. H., Edmonds, J. A., Hibbard, K. A., et al.: The next generation of scenarios for climate change research and assessment, Nature, 463, 747-756, https://doi.org/10.1038/nature08823, 2010.

Mudarra, M., Hartmann, A., and Andreo, B.: Combining experimental methods and modeling to quantify the complex recharge behavior of karst aquifers. Water Resour. Res., 55, 1384-1404, https://doi.org/10.1029/2017WR021819, 2019

Murphy, C., Wilby, R. L., Matthews, T. K. R., Thorne, P., Broderick, C., Fealy, R., Hall, J., Harrigan, S., Jones, P., McCarthy, G., MacDonald, N., Noone, S., and Ryan, C.: Multi-Century Trends to Wetter Winters and Drier Summers in the England and Wales Precipitation Series Explained by Observational and Sampling Bias in Early Records, Int. J. Climatol., 40, 610-619, https://doi.org/10.1002/joc.6208, 2019.

Naughton, O., Johnston, P. M., and Gill, L. W.: Groundwater Flooding in Irish Karst: The Hydrological Characterisation of Ephemeral Lakes (Turloughs), J. Hydrol., 470-471, 82-97, https://doi.org/10.1016/j.jhydrol.2012.08.012, 2012.

Naughton, O., Johnston, P. M., McCormack, T., and Gill, L. W.: Groundwater Flood Risk Mapping and Management: Examples from a Lowland Karst Catchment in Ireland, J. Flood Risk Manag., 10, 53-64, https://doi.org/10.1111/jfr3.12145, 2017.

Naughton, O., Gill, L. W., Johnston, P. M., Morrissey, P. J., Regan, S., McCormack, T., and Drew, D.: The Hydrogeology of the Gort Lowlands, Irish J. Earth Sci., 36, 1-20, https://doi.org/10.3318/ijes.2018.36.3, 2018.

Nerantzaki, S. D. and Nikolaidis, N. P.: The response of three Mediterranean karst springs to drought and the impact of climate change, J. Hydrol., 591, 125296, https://doi.org/10.1016/j.jhydrol.2020.125296, 2020.

Nolan, P.: Ensemble of Regional Climate Model Projections for Ireland, EPA climate change research report No. 159, EPA, Wexford, Ireland, 2015.

Nolan, P., Lynch, P. and Sweeney, C.: Simulating the future wind energy resource of Ireland using the COSMO-CLM model, Wind Energy, 17, 19-37, https://doi.org/10.1002/we.1554, 2014.

Nolan, P., O'Sullivan, J., and McGrath, R.: Impacts of Climate Change on Mid-Twenty-First-Century Rainfall in Ireland: A High-Resolution Regional Climate Model Ensem- 
ble Approach: Impacts of Climate Change on Mid-21stCentury Rainfall in Ireland, Int. J. Climatol., 37, 4347-4363, https://doi.org/10.1002/joc.5091, 2017.

Nolan, P. and Flanagan, J.: High-Resolution Climate Projections for Ireland - A Multi-model Ensemble Approach, EPA Research Report, 339, available at: http://epa.ie/pubs/reports/ research/climate/researchreport339/, last access: 11 November 2020.

Noone, S., Broderick, C., Duffy, C., Matthews, T., Wilby, R. L., and Murphy, C.: A 250-Year Drought Catalogue for the Island of Ireland (1765-2015), Int. J. Climatol., 37, 239-254, https://doi.org/10.1002/joc.4999, 2017.

O'Sullivan, J., Sweeney, C., Nolan, P., and Gleeson, E.: A highresolution, multi-model analysis of Irish temperatures for the mid-21st century. International, J. Climatol., 36, 1256-1267, https://doi.org/10.1002/joc.4419, 2015.

OPW: Climate Change Sectoral Adaption Plan - Flood Risk Managment (2019-2024), Office of Public Works, Jonathan Swift Street, Trim, Co. Meath, Ireland, 2019.

Pardo-Igúzquiza, E., Collados-Lara, A. J., and Pulido-Velazquez, D.: Potential future impact of climate change on recharge in the Sierra de las Nieves (southern Spain) high-relief karst aquifer using regional climate models and statistical corrections, Environ. Earth Sci., 78, 598, https://doi.org/10.3390/w12010219, 2019.

Pinault, J.-L., Amraoui, N., and Golaz, C.: Groundwater-Induced Flooding in Macropore-Dominated Hydrological System in the Context of Climate Changes, Water Resour. Res., 41, W05001, https://doi.org/10.1029/2004WR003169, 2005.

Porst G. and Irvine K.: Distinctiveness of macroinvertebrate communities in turloughs (temporary ponds) and their response to environmental variables Aquatic Conserv, Mar. Freshw. Ecosyst., 19, 456-465, https://doi.org/10.1002/aqc.1016, 2009.

Porst, G., Naughton, O., Gill, L., Johnston, P., and Irvine, K.: Adaptation, phenology and disturbance of macroinvertebrates in temporary water bodies, Hydrobiologia, 696, 47-62, https://doi.org/10.1007/s10750-012-1181-2, 2012.

Rauscher, S. A., Coppola, E., Piani, C., and Giorgi, F.: Resolution effects on regional climate model simulations of seasonal precipitation over Europe, Clim. Dynam., 35, 685-711, https://doi.org/10.1007/s00382-009-0607-7, 2010.
Rockel, B., Will, A., and Hense, A.: The regional climate model COSMO-CLM (CCLM), Meteorol. Z, 17, 347-348, https://doi.org/10.1127/0941-2948/2008/0309, 2008.

Shaw, E., Beven, K., Chappell, N., and Lamb, R.: Hydrology in Practice, CRC Press, London, 2011.

Shkol'nik, I. M., Meleshko, V. P., Efimov, S. V., and Stafeeva, E. N.: Changes in Climate Extremes on the Territory of Siberia by the Middle of the 21st Century: An Ensemble Forecast Based on the Mgo Regional Climate Model, Russ. Meteorol. Hydrol., 37, 71-84, https://doi.org/10.3103/S106837391202001X, 2012.

Spraggs, G., Peaver, L., Jones, P., and Ede, P.: Re-construction of historic drought in the Anglian Region (UK) over the period 1798-2010 and the implications for water resources and drought management, J. Hydrol., 526, 231-252, https://doi.org/10.1016/j.jhydrol.2015.01.015, 2015.

Taylor, R. G., Scanlon, B., Döll, P., Rodell, M., van Beek, R., Wada, Y., Longuevergne, L., Leblanc, M., Famiglietti, J. S., Edmunds, M., Konikow, L. Green, T. R., Chen, J., Taniguchi, M., Bierkens, M. F. P., MacDonald, A., Fan, Y., Maxwell, R. M., Yechieli, Y., Gurdak, J. J., Allen, D. M., Shamsudduha, M., Hiscock, K., Yeh, P. J. F., Holman, I., and Treidel, H., Ground Water and Climate Change, Nat. Clim. Change, 3, 322-329, https://doi.org/10.1038/nclimate1744, 2013.

van Vuuren, D. P., Edmonds, J., Kainuma, M. L. T., Riahi, K., Thomson, A., Matsui, T., et al.: The representative concentration pathways: an overview, Clim. Change, 109, 5-31, https://doi.org/10.1007/s10584-011-0148-z, 2011.

Waldren, S., Allott, N., Coxon, C., Cunha Periera, H., Gill, L., Gonzalez, A., Irvine, K., Johnston, P., Kimberley, S., Murphy, M., Naughton, O., O'Rourke, A., Penck, M., Porst, G., and Sharkey, N.: Turlough Hydrology, Ecology and Conservation, Unpublished Report, National Parks \& Wildlife Services, Department of Arts, Heritage and the Gaeltacht, Dublin, Ireland, 2015.

Werner, C., Nolan, P., and Naughton, O.: High-resolution Gridded Datasets of Hydro-climate Indices for Ireland, Environmental Protection Agency, Johnstown Castle, Ireland, 2019.

Winterfeldt, J., Geyer, B., and Weisse, R.: Using Quikscat in the Added Value Assessment of Dynamically Downscaled Wind Speed, 31, 1028-1039, https://doi.org/10.1002/joc.2105, 2011. 